\title{
HTLV-1 Infection and Adult T-Cell Leukemia/ Lymphoma-A Tale of Two Proteins: Tax and HBZ
}

\author{
Chou-Zen Giam ${ }^{1, *}$ and Oliver John Semmes ${ }^{2}$ \\ 1 Department of Microbiology and Immunology, Uniformed Services University of the Health Sciences, \\ 4301 Jones Bridge Rd., Bethesda, MD 20814, USA \\ 2 Department of Microbiology and Molecular Cell Biology, The Leroy T. Canoles Jr Cancer Research Center, \\ Eastern Virginia Medical School, Norfolk, VA 23501, USA; semmesoj@evms.edu \\ * Correspondence: chou-zen.giam@usuhs.edu; Tel.: +301-295-9624
}

Academic Editor: Louis M. Mansky

Received: 30 March 2016; Accepted: 1 June 2016; Published: 16 June 2016

\begin{abstract}
HTLV-1 (Human T-cell lymphotropic virus type 1) is a complex human delta retrovirus that currently infects 10-20 million people worldwide. While HTLV-1 infection is generally asymptomatic, $3 \%-5 \%$ of infected individuals develop a highly malignant and intractable T-cell neoplasm known as adult T-cell leukemia/lymphoma (ATL) decades after infection. How HTLV-1 infection progresses to ATL is not well understood. Two viral regulatory proteins, Tax and HTLV-1 basic zipper protein (HBZ), encoded by the sense and antisense viral transcripts, respectively, are thought to play indispensable roles in the oncogenic process of ATL. This review focuses on the roles of Tax and HBZ in viral replication, persistence, and oncogenesis. Special emphasis is directed towards recent literature on the mechanisms of action of these two proteins and the roles of Tax and HBZ in influencing the outcomes of HTLV-1 infection including senescence induction, viral latency and persistence, genome instability, cell proliferation, and ATL development. Attempts are made to integrate results from cell-based studies of HTLV-1 infection and studies of HTLV-1 proviral integration site preference, clonality, and clonal expansion based on high throughput DNA sequencing. Recent data showing that Tax hijacks key mediators of DNA double-strand break repair signaling-the ubiquitin E3 ligase, ring finger protein 8 (RNF8) and the ubiquitin E2 conjugating enzyme (UBC13)-to activate the canonical nuclear factor kappa-light-chain-enhancer of activated B-cells (NF- $\mathrm{kB}$ ) and other signaling pathways will be discussed. A perspective on how the Tax-RNF8 signaling axis might impact genomic instability and how Tax may collaborate with HBZ to drive oncogenesis is provided.
\end{abstract}

Keywords: HTLV-1; senescence; latency and persistence; RNF8; UBC13; K63-linked polyubiquitin; DNA damage response; genomic instability; adult T-cell leukemia

\section{HTLV-1 Infection and Adult T-Cell Leukemia}

Human T-cell lymphotropic virus type 1 (HTLV-1) is a complex human delta retrovirus that infects 10-20 million people worldwide [1]. HTLV-1 Infection is mostly asymptomatic. However, via mechanisms that are not fully understood, 3\%-5\% of infected individuals develop a highly aggressive malignancy known as adult T-cell leukemia/lymphoma (ATL) decades after infection [2,3]. HTLV-1 infection also leads to several inflammatory and immune-mediated disorders, most notably HTLV-1-associated myelopathy (HAM)/tropical spastic paraparesis (TSP). ATLs are clinically classified as acute, lymphomatous, chronic, and smoldering types, with smoldering ATL possibly representing the early stage of the disease that often progresses to acute ATL over time [4]. There is also a pre-ATL state characterized by the presence of peripheral lymphocytes that display abnormal morphology resembling ATL cells. 
The leukemic cells of ATL are monoclonal and harbor HTLV-1 proviral DNA at random chromosomal integration sites. Two viral regulatory proteins, Tax and HTLV-1 basic zipper protein (HBZ), encoded by the sense and antisense viral transcripts, respectively, are thought to play indispensable roles in the oncogenic process of ATL [3,5]. Tax is a potent activator of viral transcription and I kappa B kinase (IKK) / nuclear factor kappa-light-chain-enhancer of activated B-cells (NF-kB) signaling. It also exerts pleiotropic effects on cell signaling. HBZ, by contrast, antagonizes many of the activities of Tax. A recent whole-genome/exome/transcriptome analysis of a large cohort of ATL patients has revealed recurrent activating mutations in phospholipase $\mathrm{C} \gamma 1$ (PLCG1) (36\%), protein kinase $\mathrm{C} \beta$ (PKCB) (33\%), caspase recruitment domain-containing protein 11 (CARD11) (24\%), disks large homolog 1 (DLG1) (24\%), vav guanine nucleotide exchange factor 1 (VAV1) (18\%), and cluster of differentiation 28 (CD28) (18\%) in ATL samples [6]. These genetic alterations converge on the T-cell receptor-NF- $\mathrm{kB}$ and the $\mathrm{CD} 28$ co-stimulatory signaling pathways, and show remarkable functional overlap with the Tax interactome [6]. Tax expression, however, is frequently lost from ATLs ( $47 / 48$ cases examined). By contrast, the expression of the HBZ antisense transcript is ubiquitous [6]. The loss of Tax expression from ATL cells suggests that the oncogenic effects of Tax are exerted early during ATL development, with HBZ playing a role in ATL maintenance [7-10]. Unlike other hematological malignancies, ATLs are noted for extensive genomic instability, a feature that has been fully borne out by the whole-genome analysis mentioned above, showing 59.5 structural variations / ATL sample and 7.9 point mutations $/ 10^{6}$ bases, almost thrice that of multiple myeloma ( 21 chromosomal rearrangements/sample and 2.9 point mutations $/ 10^{6}$ bases) [11]. Although the molecular basis for the genomic instability of ATL is not fully understood, earlier studies have implicated a link to Tax, which represses DNA damage repair (DDR) and disrupts mitotic processes [12-15].

\section{HTLV-1 Viral Gene Expression and Regulation}

In addition to structural proteins Gag, Pol, and Env, HTLV-1 encodes six viral accessory proteins, Tax, Rex, $\mathrm{p} 12^{\mathrm{I}}, \mathrm{p} 13^{\mathrm{II}}, \mathrm{p} 30^{\mathrm{II}}$, and HBZ from partially overlapping open reading frames (ORFs) in both directions of the viral genome. For a more recent review on $\mathrm{p} 12^{\mathrm{I}}, \mathrm{p} 13^{\mathrm{II}}$, and $\mathrm{p} 30^{\mathrm{II}}$, the reader is referred to this article [16]. P12 ${ }^{\mathrm{I}}$, a membrane-associated protein, appears to play a role in enhancing T-cell activation and signaling, although contradictory findings have also been described. A recent paper has reported p12 ${ }^{\mathrm{I}}$-mediated down-regulation of intercellular adhesion molecules ICAM-1 and ICAM-2, which is thought to mitigate autologous natural killer cell cytotoxicity for the infected CD4+ T-cells [17]. $\mathrm{p} 12^{\mathrm{I}}$ and its proteolytic cleavage product $\mathrm{p} 8$ are critical for HTLV-1 viral persistence and spread in vivo, and in keeping with these functions, $\mathrm{p} 12^{\mathrm{I}}$ has been reported to bind major histocompatibility complex (MHC) class I heavy chain and targets it for degradation [18]. The $\mathrm{p} 13^{\mathrm{II}}$ is an inner mitochondria membrane protein with anti-proliferation activity [19]. It also becomes ubiquitinated in the presence of Tax and translocates to the nucleus, where it disrupts Tax-CREB binding protein (CBP)/p300 interaction and inhibits viral and cellular transcription [20]. Its role in the HTLV-1 infection and replication cycle is not fully defined. The anti-proliferation activity of $\mathrm{p} 13^{\mathrm{II}}$ appears to be related to an interaction with farnesyl pyrophosphate synthetase [21] and the increased sensitivity to $\mathrm{Ca}^{2+}$-mediated stimulation and enhanced C2-ceramide-induced apoptosis of $\mathrm{p} 13^{\mathrm{II}}$-expressing $\mathrm{T}$ lymphocytes [22]. $\mathrm{p} 30^{\mathrm{II}}$ is a nuclear protein that functions as a post-transcriptional modulator of viral replication. Data suggest that $\mathrm{p} 30^{\mathrm{II}}$ retains the doubly-spliced tax/rex mRNA in the nucleus and thereby down-modulates viral gene expression by reducing the levels of Tax and Rex [16,23]. Rex regulates the transport of unspliced and singly-spliced mRNA, while Tax, the viral transcriptional activator, is thought to be the source of HTLV-1's oncogenic potential. Tax expression is sufficient to effect cellular transformation in rodent fibroblasts and in primary human lymphocytes, and expression of Tax through a variety of promoters induces neoplasia in transgenic mice. In promoting viral replication, HTLV-1 Tax interacts with cellular regulators of homeostasis; these interactions ultimately perturb a number of basic cellular processes, many or all of which contribute to leukemia development. The major anti-sense HBZ mRNA, spliced HBZ (sHBZ), spans the open sequence between the env and the tax/rex ORFs. The region of the 
transcript complementary to the tax/rex mRNA is removed by splicing and, therefore, not expected to affect tax/rex mRNA by RNA interference. Similarly, a minor unspliced HBZ (usHBZ) transcript has its transcriptional start site upstream of the tax/rex region, and hence does not affect Tax/Rex. Both sHBZ and usHBZ mRNAs encode, respectively, basic domain-leucine zipper proteins with minor differences in their respective $\mathrm{NH}_{2}$-termini, and both forms of $\mathrm{HBZ}$ have been shown to negatively regulate Tax trans-activation [24] (see below). Importantly, the spliced HBZ protein and RNA are expressed in all ATL cells and can stimulate cell proliferation [5].

\section{HTLV-1 Infection and Its Outcomes}

\subsection{HTLV-1 Transmission Requires Cell-to-Cell Contacts}

HTLV-1 infection is highly dependent on cell propagation. Human transmission of HTLV-1 requires the transfer of virus-infected cells via breast-feeding, sexual intercourse, transfusion of cell-containing blood components, and needle sharing; all suggest a mechanism that depends upon cell-cell transfer. In vitro, HTLV-1 infects a wide variety of cells, including T and B lymphocytes, monocytes, endothelial cells, and fibroblasts. This is due in part to its use of a ubiquitous cell surface molecule, the glucose transporter 1, as the receptor for virus entry [25]. Other molecules, such as neuropilin-1 and heparan sulfate proteoglycans, also contribute to viral infection [26,27]. The broad tropism of HTLV-1 notwithstanding, its transmission requires cell-to-cell contact [28-30]. Cell-free HTLV-1 viral particles are poorly or not infectious directly [6]. The difference in efficiency between cell-mediated and cell-free infection is in the order of $10^{5}$ to 1 [31]. Cell-to-cell transmission of HTLV-1 occurs through the "virological synapse" formed in part through lymphocyte function-associated antigen 1 (LFA1) and ICAM1 [29,32]. Tax expression and ICAM1 engagement cause the microtutule polarization associated with the virological synapse. Tax is also localized to the region of the cell-cell contact formed between an HTLV-1 donor cell and its target cell, and at the vicinity of the microtubule-organizing center associated with the cis-Golgi [32,33]. Interestingly, it has been shown recently that dendritic cells exposed to free HTLV-1 particles not only become productively infected themselves (cis-infection), but can also rapidly transmit the virus to CD4+ T-cells (trans-infection) [34-36] (reviewed in [37]). HTLV-1 viral particles have also been found to be stored as carbohydrate-rich, biofilm-like extracellular assemblies that rapidly attach to target cells for virus transmission [38]. Finally, the presence of viral proteins in exosomes suggests a role for cell-derived microvesicles in HTLV-1 infection [39]. One might envision microvesicles as assisting virus transfer to naive cells, facilitating the delivery of bioactive viral proteins, or sequestration of immune-reactive viral proteins.

\subsection{Evolution of HTLV-1-Infected T-Cells In Vivo}

The details of the early events of acute HTLV-1 infection in humans are unknown. Analyses of chronic HTLV-1 infection in affected individuals have indicated that the HTLV-1 proviral DNA sequences show little nucleotide variations, suggesting that viral replication via error-prone reverse transcription occurs infrequently [40]. In asymptomatic carriers (ACs), HTLV-1 viral particles, mRNAs, and proteins, are virtually undetectable. The "latent" HTLV-1 genome is maintained in infected T-cells through limited mitotic division, presumably accompanied by occasional re-activation and de novo infection. ATL is usually characterized by the monoclonal expansion of a single leukemic cell that harbors the HTLV-1 proviral DNA integrated at a clone-specific chromosomal locus. Tax expression is largely silenced in ATL cells. This has been attributed to the negative selection of Tax-expressing cells by Tax-specific cytotoxic T lymphocyte-mediated killing [41-43].

\subsection{Clonal Expansion of HTLV-1-Infected T-Cells In Vivo}

Because very little HTLV-1 replication and gene expression can be detected in infected individuals, proviral DNA load (PVL) has been used as a quantitative measure of viral infection. Longitudinal studies of newly infected seroconverters and ACs have indicated that the clonality of HTLV-1-infected 
T-cells is more heterogeneous and unstable in the former [44]. Using the inverse-long PCR procedure to analyze PVLs and clonality of ATL and pre-diagnostic peripheral blood mononuclear cells (PBMCs) (3-8 years prior to ATL onset), Okayama et al. have reported that prior to the disease onset, there is a significant rise in PVLs. In one ATL case for which both leukemic and pre-diagnostic samples are available, pre-leukemic cells harboring the same integrated provirus as the leukemic cells could be detected 2, 5, and 8 years prior to ATL diagnosis, supporting the notion that persistent clonal expansion, selection, and evolution drive ATL development [45]. In a separate study, Umeki et al. have analyzed longitudinal samples collected over a period of more than a decade from a group of three Jamaican carrier children who acquired HTLV-1 perinatally [46]. The study indicates that the HTLV-1 PVLs are variable $\left(10^{2}-10^{3}\right.$ copies $/ 10^{5}$ PBMCs $)$ in ACs. Some of these clones persisted for years, and two unique clones in one subject underwent significant expansion a decade or longer after the initial infection, causing PVLs to increase more than 40 -fold, from $3 \times 10^{3}$ to $1.3 \times 10^{4}$ copies $/ 10^{5}$ PBMCs. While the clonal expansion did not result in HAM/TSP or ATL, lymphadenopathy, seborrheic dermatitis, and hyperreflexia were observed in the subject [46].

More recently, high-throughput DNA sequencing has been used to characterize the chromosomal integration sites of HTLV-1 proviral DNA and the clonality of infected cells in ACs, and HAM/TSP and ATL patients (reviewed in [47]). These studies have demonstrated that the size of each proviral clone in ACs varies within the range of $<1-10^{3}$ per $10^{5} \mathrm{PBMC}$, and a large majority of infected cells harbor a single integrated provirus [48]. In agreement with this finding, in $91 \%$ of ATL cases, a predominant and presumably malignant T-cell clone containing one single provirus is detected [49]. An earlier study has shown that the integration pattern of an HTLV-1 vector devoid of viral genes in HeLa cells is randomly dispersed and shows a moderate preference for transcriptional start sites and CpG islands [50]. Similar integration site preferences were found in vivo (in infected individuals) and in vitro (cell culture-based infection) [51].

HTLV-1 clones that persist in chronically infected persons show little detectable Tax mRNA or protein expression in vivo and ex vivo, and silencing of Tax expression via 5'-long terminal repeat (LTR) methylation, $5^{\prime}$-LTR deletion, or nonsense mutations within its coding sequence is correlated with the expansion of malignant T-cells $[52,53]$. The $3^{\prime}$ region of the viral genome and the 3'-LTR, however, remain intact and unmethylated, thus favoring HBZ expression [53]. In vitro culture of infected but Tax-negative T-cells from donors induce Tax expression, but clones that remain Tax-negative in culture are more abundant [47]. Although Tax silencing correlates with clone abundance in vivo, the HTLV-1 proviral DNAs often integrate within genes and in transcriptionally active regions of the genome, and the integration properties of ATL clones are similar to those of ACs. Such an integration pattern is thought to favor HBZ expression. It also suggests that, upon integration, the chromosomal integration loci initially favor Tax and viral gene expression/replication, but are later silenced epigenetically when the infection enters into the chronic phase. While the loss of Tax and sense mRNA expression has been attributed to the negative selection pressure exerted by the host immune system (Tax-specific cytotoxic T lymphocytes (CTLs)) on virus-infected cells [41-43], the cellular senescence response triggered by Tax during productive infection in cell culture most likely also plays a role (discussed below) [54-57].

\subsection{HTLV-1 Infection in Cell Culture}

HTLV-1 infection in cell culture is usually achieved by co-cultivation of naïve PBMCs with mitotically inactivated HTLV-1-producing cells $[58,59]$ or by cell-free infection using vesicular stomatitis virus (VSV) G-pseudotyped viral particles [30]. As the efficiency of infection is poor and the detection of newly infected cells is technically challenging, studies of the outcome of HTLV-1 infection often involve long-term culture of infected PBMCs, with immortalization/transformation of virus-infected primary CD4+ T-cells as the experimental end-point [58]. As the early events of viral infection are difficult to study, they have not been examined in depth, and the mitogenic effects of HTLV-1 infection and Tax are assumed largely based on results from T-cell immortalization and tumor development in Tax-transgenic models that occur long after viral infection and Tax transgene expression [60-62]. In the meantime, with 
only a few exceptions [63], constitutive expression of Tax in cultured cell lines is virtually impossible to achieve, suggesting that in order for Tax to drive cell immortalization/transformation and oncogenesis, specific cellular alterations are needed or alternative viral factor(s) is (are) involved.

\subsection{HTLV-1 Infection in Rabbits}

Of the animal models of HTLV-1 infection, the rabbit model is perhaps the most amenable to experimentation, although none of the human diseases associated with HTLV-1 infection have been recapitulated therein $[64,65]$. With this system, Li et al. have shown that the tax/rex mRNA levels in PBMCs peak one week after inoculation of rabbits with $\gamma$-irradiated HTLV-1-produing cells [66]. They then rapidly declined to low levels when the infection progressed beyond the second week. As might be expected, gag-pol mRNA expression is coincident with, but at levels that are approximately one quarter that of the levels of tax/rex mRNA, and became mostly undetectable two to three weeks after infection. By contrast, HBZ mRNA levels were low at the start of the infection, but slowly increased and stabilized at four weeks and beyond. This is then followed by a rise in the proviral DNA load that mostly peaked at six weeks after inoculation. These results suggest that immediately after HTLV-1 infection, there is a strong selective pressure to silence viral gene expression, and only cells expressing Tax/Rex and HBZ at low and steady levels, respectively, persist. Whether the rapid decline in Tax/Rex and Gag-Pol expression soon after infection is due solely to the elimination of infected cells by CTL is unclear. As detailed below, the senescence response triggered by Tax may also play a key role in selecting for infected cells that express viral genes minimally.

\subsection{Tax, NF-kB Hyperactivation, and Senescence}

As HTLV-1 causes ATL in vivo and transforms T-cells in cell culture, it is widely accepted that HTLV-1 infection causes T-cells to proliferate [3]. Because HTLV-1 Tax potently activates viral transcription, and NF-KB and other signaling pathways, it has been proposed that, via these activities of Tax, especially NF- $\mathrm{kB}$ activation, HTLV-1-infected T-cells are stimulated to proliferate, which eventually results in ATL. However, early studies describing the ability of Tax to compliment Ras but repress Myc in promoting anchorage-dependent growth clearly demonstrated that the cellular genetic background greatly influences the outcome of Tax expression [67,68].

We have used several lymphoid (Jurkat and SupT1) and non-lymphoid (HeLa and HOS) reporter cell lines to investigate the early cellular response to HTLV-1 infection in culture $[54,55,69]$. Contrary to the prevailing thinking that HTLV-1 infection leads to cell proliferation, our results show that most HTLV-1-infected lymphoid or non-lymphoid cells cease proliferation one cell division cycle after infection $[54,55,69]$. The infected cells express high levels of cyclin-dependent kinase inhibitors: p21 ${ }^{\mathrm{CIP} 1 / \mathrm{WAF} 1}$ (p21) and p27 ${ }^{\mathrm{KIP1}}$ (p27), develop mitotic abnormalities often with cytokinesis failure [56], and become arrested in senescence driven by Tax-mediated hyperactivation of NF-kB [57]. These results are in agreement with the induction of G1 cell cycle arrest seen with CD34+ hematopoietic progenitor cells infected by HTLV-1 in culture [70]. The dramatic rise in p21 and p27 in response to Tax is due to transcriptional up-regulation in conjunction with mRNA stabilization (of p21) [56,57,71], and protein stabilization (of p27) as a result of S-phase kinase-associated protein 2 (Skp2) degradation caused by the prematurely activated anaphase-promoting complex [56,72]. When NF- $\mathrm{kB}$ is repressed in HeLa or HOS cells by the stable expression of a degradation-resistant mutant of inhibitor of kappa $B$ $(\mathrm{I} \kappa \mathrm{B} \alpha), \Delta \mathrm{N}-\mathrm{I} \kappa \mathrm{B} \alpha$, the senescence response triggered by HTLV-1 infection is mitigated [57], the cell lines that are chronically infected by HTLV- 1 and express all viral proteins can be readily established $[55,69]$. Indeed, chronically infected HTLV-1-producing NF-KB-repressed HOS cell lines could transmit the virus to Jurkat T-cells [69]. These results suggest that most HTLV-1 infections induce a senescence response mediated by hyperactivated NF- $\mathrm{kB}$. This is contrary to the belief that Tax-dependent NF- $\mathrm{KB}$ activation immediately promotes HTLV-1-infected T-cells to undergo clonal expansion, leading to ATL development. Thus, in order for Tax to promote oncogenesis, the cellular senescence response would have to be inactivated first [73]. Tax is also known to cause apoptosis in an NF-kB-dependent manner in a variety of lymphoid and non-lymphoid cell lines and experimental settings [74-80]. The senescence and apoptosis responses induced by Tax are mechanistically linked to NF- $\mathrm{kB}$ activation, 
possibly with the choice between senescence and apoptosis dependent on the genetic makeup or biological characteristics of the infected cells. It is reasonable to think that both senescence and apoptosis constitute cellular responses to potentially oncogenic NF-kB hyperactivation that occurs during productive HTLV-1 infection. Thus, in addition to CTL-mediated killing, the innate cellular mechanism that guard against NF- $\mathrm{KB}$ hyperactivation also drives the elimination of cells that are productively infected by HTLV-1, thereby allowing only "latently" infected cells with minimal to no viral (sense) gene expression to persist. The expansion of these cells will have to depend mostly on HBZ, a low level of Tax, somatic mutations that are mitogenic, or a combination of these three.

\subsection{Does Cellular Senescence Facilitate the Spread of HTLV-1 to Innate Immune Cells?}

As the majority of HTLV-1-infected cells become senescent, the question immediately arises as to why HTLV-1 retains such a self-limiting mechanism for viral replication. Is senescence just a cellular response to prevent NF- $\mathrm{KB}$ hyperactivation, and thus indirectly impacts HTLV-1 replication, or alternatively, could the biological properties of senescent cells be exploited by HTLV-1 for its unique lifestyle (Figure 1)? Studies of oncogene-induced senescence have demonstrated that factors secreted by senescent cells attract cells of the innate immune system, including natural killer (NK) cells, neutrophils, and macrophages, for their clearance (reviewed in [81]). As macrophages are highly proficient in spreading HTLV-1 to CD4+ T-cells, it would be interesting to investigate whether productively infected HTLV-1-producing cells that become senescent can efficiently recruit macrophages as conduits for transmitting HTLV-1.

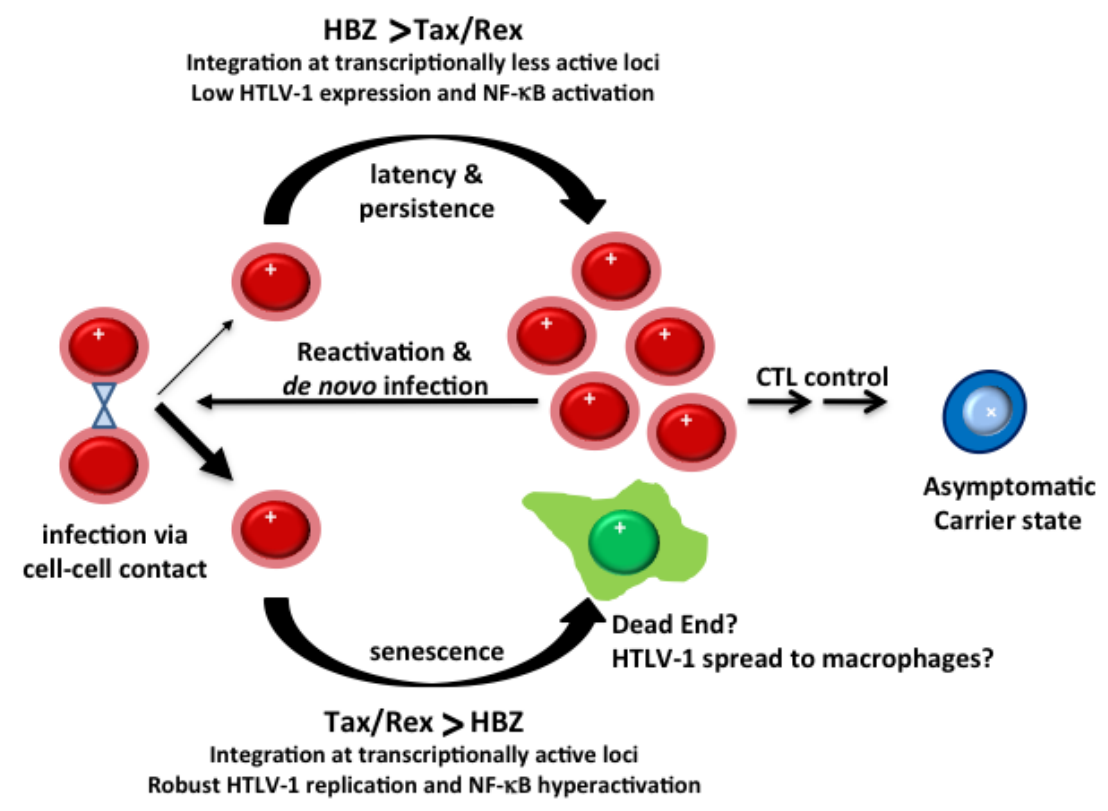

Figure 1. Outcomes of HTLV-1 (Human T-cell lymphotropic virus type 1) infection. Proviral integration sites determine the levels of Tax/Rex expression in infected cells. During productive infection, high levels of Tax/Rex override HTLV-1 basic zipper protein (HBZ)-dependent inhibition to promote productive viral replication, nuclear factor kappa-light-chain-enhancer of activated B-cells (NF- $\kappa \mathrm{B}$ ) hyperactivation, and cellular senescence. Approximately $98 \%$ of HeLa cells infected by HTLV-1 in culture become senescent [55]. When the levels of Tax/Rex are low, long terminal repeat (LTR) trans-activation, NF- $\kappa B$ activation, and senescence induction by Tax and viral mRNA nuclear export by Rex are inhibited by HBZ. As such, no viral structural proteins are expressed and the "latently" infected cells undergo mitotic expansion, likely propelled by HBZ and complemented by Tax that is expressed at subdued levels. The latent virus intermittently reactivates to initiate de novo HTLV-1 infection. The silencing of Tax and positive-sense viral mRNA expression are further selected by cytotoxic T lymphocyte (CTL) killing, resulting in an asymptomatic carrier state with little detectable serum levels of viral components. 


\section{Oligoclonal Expansion of HTLV-1-Infected Cells}

\subsection{HBZ Mitigates the Senescence Response Induced by Tax and Promotes "Latent" HTLV-1 Infection}

HBZ antagonizes many of the activities of Tax, including LTR and NF- $\mathrm{KB}$ activation $[57,82-85]$ (see below for additional details). We have found that, even though the majority of NF- $\mathrm{kB}$-normal HeLa cells become senescent after HTLV-1 infection, a small population manages to continue to proliferate after infection and expresses low but detectable levels of Tax and Rex, albeit not Gag or Env [55]. In these cells, HTLV-1 LTR trans-activation by Tax continues at a reduced level, but NF- $\mathrm{kB}$ trans-activation is attenuated due to inhibition by HBZ. Interestingly, in these cells, gag-pol mRNA was found to localize primarily in the nuclei because Rex-mediated export of intron-containing mRNAs is blocked by HBZ [55]. Hence, during HTLV-1 infection, when Tax/Rex expression is robust and dominant over HBZ, productive infection ensues with expression of structural proteins and NF- $k B$ hyperactivation, which induces senescence. When Tax/Rex expression is at a low level, HBZ attenuates Tax-driven canonical NF- $\kappa \mathrm{B}$ activation [86], mitigates senescence induction, and allows infected cells that express viral genes minimally to proliferate and undergo clonal expansion [55,57]. In this "latent" state, HTLV-1-infected cells express Tax/Rex minimally or not at all, a low but steady level of HBZ, and no viral structural proteins. HBZ maintains viral latency by down-regulating Tax/Rex functions. Indeed, multiple lines of evidence support the notion that HBZ can promote "latently" infected cells to proliferate, and by so doing expand the reservoir of T-cells harboring the proviral genome $[9,10]$. It should also be noted that, when expressed at low levels, Tax may activate cell signaling to facilitate survival or expansion of infected cells. These findings are schematically summarized in Figure 1. Further investigation of the molecular aspects of HTLV-1 "latent" infection is needed to better understand the role in disease development.

\subsection{Attenuation of NF-KB Activation and Loss of Senescence Response Facilitate Clonal Expansion of HTLV-1-Infected Cells in Vitro}

Based on the premise that NF- $\kappa B$ hyperactivation by Tax drives senescence induction after viral infection, the inhibition of NF- $\mathrm{kB}$ activation and the loss of the $\mathrm{p} 21 / \mathrm{p} 27$-driven senescence response should promote expansion of Tax-expressing HTLV-1-infected cells [87]. Indeed, HeLa and HOS cell lines expressing the degradation-resistant NF- $k B$ super-repressor, $\Delta \mathrm{N}-\mathrm{I} \kappa \mathrm{B} \alpha$, can be productively infected [55]. Chronically infected NF-kB-repressed HOS clones in particular were able to transmit HTLV-1 to target T-cells with ease [69]. Thus, clonal expansion of HTLV-1-infected T-cells with significant Tax expression can occur after (a) attenuation/inhibition of IKK/NF-KB activation and/or (b) inactivation/loss of cellular senescence response. In this vein, it is interesting to note that the master transcriptional regulatory factor, forkhead box P3 (Foxp3), which is responsible for the development of $\mathrm{T}$ regulatory (Treg) cells [88], is a potent inhibitor of the transcriptional activities of cAMP response element-binding protein (CREB) / activating transcription factor (ATF), NF- $\mathrm{kB}$, and nuclear factor of activated T-cells (NFAT) $[89,90]$, and many HTLV-1-infected T-cells and ATL cells are CD4+, CD25high, and Foxp3+, and exhibit characteristics of Treg cells [91]. According to the model described above, Foxp3+ T cells would be better equipped to undergo clonal expansion after HTLV-1 infection. It is well established that p21 expression is highly induced in HTLV-1-transformed T-cell lines, but most likely is functionally inactivated or redirected to functions other than G1 cell cycle arrest [71,92], and is largely lost from ATL cells [93]. Further, in correlation with increased cell cycle entry, p27 protein expression is often greatly reduced in HTLV-1-transformed T-cell lines via the phosphatidylinositol-4,5-bisphosphate 3 (PI3)-kinase pathway [56,73]. ATL cell lines are therefore expected to be impaired in or to have lost the senescence response induced by HTLV-1 infection. Our unpublished results indicate that most ATL cell lines (ED, MT-1, ATL-55T, and TL-Om1) indeed continue to proliferate after re-infection by HTLV-1. 


\section{HTLV-1 Tax, Genomic Instability, and ATL Development}

\subsection{ATLs Are Associated with Extensive Genomic Instability}

Unlike other hematological malignancies, ATLs are characterized by extensive genomic instability, a feature that has been fully borne out by an integrated whole-genome analysis of ATL samples [6]. The molecular basis for the genomic instability of ATLs is linked to the HTLV-1 viral oncoprotein Tax, which, in addition to being a potent activator of viral transcription and IKK/NF- $\mathrm{kB}$ signaling, inhibits DNA double-strand break (DSB) repair, induces micronuclei formation, and disrupts spindle assembly and cytokinesis $[3,12,94]$.

\subsection{Tax and DNA Double-Strand Breaks}

Micronuclei are extra-nuclear chromosomal fragments or whole chromosomes that form as a result of chromosome breaks (clastogenic events) or chromosome lagging during cell division. The induction of micronuclei formation by Tax has long been noted [13], and is associated with increased free DNA 3' ends that are consistent with frequent occurrence of clastogenic DSBs [14]. In fact, genomic instability, as measured by the induction of micronuclei, represents one of the few differences in the biological activity of HTLV-1 Tax1 versus HTLV-2 Tax2 [15]. Tax expression can also increase the rate of gene amplification, as revealed by the $\mathrm{N}$-(phosphonoacetyl)-L-aspartate-resistance (PALA) assay, which measures increased copy number of the carbamyl phosphate synthetase/aspartate transcarbamylase/dihydro-orotase (CAD) gene caused by DNA recombination following DSBs [95].

Mechanistically, there have been numerous Tax activities reported to result in genomic instability (summarized in Table 1). Early on, Tax has been found to repress the expression of DNA Pol $\beta$, a DNA polymerase involved in base excision repair [96]. Recent studies have found the expression of Tax to result in the accumulation of reactive oxygen species (ROS) [80] and NO [97], each of which induces DSBs. Tax has also been shown to directly repress the cellular DDR (for a review see [12]). We have described that Tax induces the formation of DNA damage-independent nuclear foci that contain DDR mediators such as breast cancer 1 (BRCA1), checkpoint kinase 2 (CHK2), DNA-dependent protein kinase (DNA-PK), and mediator of DNA damage checkpoint protein 1 (MDC1) [98-101]. The recruitment of one of these factors, MDC1, was competitive with the formation of DNA damage-induced foci and suggests that Tax represses cellular DDR via sequestration of MDC1 [98]. Whether Tax directly induces DSBs, inhibits the repair of DSBs, or both, has not been fully delineated. Our recent data showing that Tax hijacks DDR signal transducers, the ubiquitin E3 ligase, ring finger protein 8 (RNF8), and the ubiquitin $\mathrm{E} 2$ conjugating enzyme, UBC13, for IKK/NF- $\mathrm{KB}$ activation [102] (see below) may begin to provide a clear mechanistic understanding for how HTLV-1 infection leads to DNA damage, genomic instability, and ATL development.

Table 1. A comparison of the activities and functional consequences of Tax and HTLV-1 basic zipper protein (HBZ).

\begin{tabular}{cccc}
\hline Tax Activities & $\begin{array}{c}\text { Functional } \\
\text { Consequences }\end{array}$ & HBZ Activities & $\begin{array}{c}\text { Functional } \\
\text { Consequences }\end{array}$ \\
\hline $\begin{array}{c}\text { CREB, CBP/p300, } \\
\text { P/CAF, TORC } \\
\text { interaction }\end{array}$ & $\begin{array}{c}\text { Activate viral } \\
\text { transcription }\end{array}$ & $\begin{array}{c}\text { CREB, CBP/p300 } \\
\text { interaction }\end{array}$ & $\begin{array}{c}\text { Suppress viral gene } \\
\text { expression }\end{array}$ \\
\hline Association with MTOC & $\begin{array}{c}\text { Promote formation of } \\
\text { virological synapse and } \\
\text { cell-cell transmission }\end{array}$ & $\begin{array}{c}\text { Rex inhibition } \\
\text { puppress viral gene } \\
\text { production }\end{array}$ \\
\hline
\end{tabular}


Table 1. Cont.

\begin{tabular}{|c|c|c|c|}
\hline Tax Activities & $\begin{array}{c}\text { Functional } \\
\text { Consequences }\end{array}$ & HBZ Activities & $\begin{array}{c}\text { Functional } \\
\text { Consequences }\end{array}$ \\
\hline $\begin{array}{l}\text { RNF8, UBC13 interaction } \\
\text { and activation }\end{array}$ & $\begin{array}{c}\text { Stimulate K63-linked } \\
\text { polyubiquitin chain } \\
\text { assembly }\end{array}$ & $\begin{array}{l}\text { NF-kB DNA-binding } \\
\text { disruption and } \\
\text { p65/RelA degradation }\end{array}$ & $\begin{array}{l}\text { Suppress Tax-mediated } \\
\text { canonical NF- } \mathrm{B} B \\
\text { activation }\end{array}$ \\
\hline $\begin{array}{l}\text { TAK1, IKK, MKK, JNK, } \\
\text { mTOR, etc. activation }\end{array}$ & $\begin{array}{c}\text { Activate c-Jun/AP } \\
\text { and SRF }\end{array}$ & & $\begin{array}{l}\text { Prevent senescence } \\
\text { induction }\end{array}$ \\
\hline $\begin{array}{c}\text { Canonical NF- } \mathrm{kB} \\
\text { activation }\end{array}$ & $\begin{array}{l}\text { Induce expression of } \\
\text { cytokines, cytokine } \\
\text { receptors, adhesion }\end{array}$ & & $\begin{array}{l}\text { Promote viral latency } \\
\text { and persistence of } \\
\text { virus-infected cells }\end{array}$ \\
\hline & $\begin{array}{l}\text { molecules, anti-apoptotic } \\
\text { factors, etc. }\end{array}$ & & \\
\hline $\begin{array}{l}\mathrm{p} 21^{\mathrm{WAF} 1} \text { and } \mathrm{p} 27^{\mathrm{KIP} 1} \\
\text { up-regulation }\end{array}$ & Induce senescence & & \\
\hline \multirow[t]{3}{*}{$\begin{array}{l}\text { NIK, p100 interaction } \\
\text { Non-canonical } \\
\text { NF- } \kappa \text { B activation }\end{array}$} & $\begin{array}{l}\text { Induce expression of } \\
\text { cytokines, cytokine }\end{array}$ & E2F1 activation & $\begin{array}{l}\text { Promote cell } \\
\text { proliferation }\end{array}$ \\
\hline & molecules, anti-apoptotic & & \\
\hline & & $\begin{array}{l}\text { Survivin up-regulation } \\
\text { (HBZ RNA) }\end{array}$ & Prevent apoptosis \\
\hline $\begin{array}{l}\text { CDK } 2 / 4 \text { activation } \\
\text { E2F1 activation }\end{array}$ & $\begin{array}{l}\text { Promote cell cycle } \\
\text { progression }\end{array}$ & Onco-miRs activation & $\begin{array}{l}\text { Promote cell } \\
\text { proliferation }\end{array}$ \\
\hline Cyclin D1 activation & & hTERT activation & \\
\hline $\begin{array}{l}\text { P53, Rb, DLG1 } \\
\text { inactivation }\end{array}$ & & BDNF/TrkB activation & \\
\hline PCNA activation & & $\begin{array}{l}\text { Wnt5a, JunD activation } \\
\text { CENP-B repression }\end{array}$ & \\
\hline hTERT activation & $\begin{array}{c}\text { Promote cell } \\
\text { immortalization }\end{array}$ & $\begin{array}{l}\text { Foxp3 induction and } \\
\text { functional inactivation }\end{array}$ & Modify T-cells \\
\hline P53 inactivation & $\begin{array}{l}\text { Induce genomic } \\
\text { instability }\end{array}$ & $\begin{array}{l}\text { Bim repression } \\
\text { via Foxo3a }\end{array}$ & $\begin{array}{l}\text { Promote cell survival } \\
\text { during stress response }\end{array}$ \\
\hline $\begin{array}{l}\text { Sequestration of DDR } \\
\text { mediator MDC1 }\end{array}$ & & IFN $\gamma$ repression & \\
\hline $\begin{array}{c}\text { Inactivation of DDR } \\
\text { mediators CHK1 } \\
\text { and } \mathrm{CHK} 2\end{array}$ & & $\begin{array}{c}\text { Activation of } \\
\text { mTOR/suppression of } \\
\text { autophagy }\end{array}$ & \\
\hline \multicolumn{4}{|l|}{$\begin{array}{l}\text { Suppression of DNA } \\
\text { Pol } \beta \text { expression }\end{array}$} \\
\hline Activation of APC/C & $\begin{array}{l}\text { Promote aneurploidy, } \\
\text { cytokinesis defect, } \\
\text { and senescence }\end{array}$ & TIGIT induction & $\begin{array}{c}\text { Impair antiviral } \\
\text { immunity and promote } \\
\text { immune evasion }\end{array}$ \\
\hline $\begin{array}{c}\text { RANBP1, TaxBP2 } \\
\text { (Rootletin isoform 2) } \\
\text { interaction }\end{array}$ & $\begin{array}{l}\text { Promote centrosome } \\
\text { amplification or } \\
\text { fragmentation }\end{array}$ & & \\
\hline \multicolumn{4}{|c|}{$\begin{array}{l}\text { CREB: cAMP response element-binding protein; CBP/p300: Tax-CREB binding protein (CBP)/p300; } \\
\text { P/CAF: p300/CBP-associated factor; TORC: transducers of regulated CREB; MTOC: microtubule organizing } \\
\text { centers; RNF8: ring finger protein 8; UBC13: ubiquitin E2 conjugating enzyme; NF-kB: nuclear factor } \\
\text { kappa-light-chain-enhancer of activated B-cells; TAK1: TGF } \beta \text { )-activated kinase 1; IKK: I kappa B kinase; MKK: } \\
\text { mitogen-activated protein kinase kinase; JNK: c-Jun N-terminal kinase; mTOR: mammalian target of rapamycin; } \\
\text { AP: activator protein; SRF: serum response factor; NIK: NF-kB-inducing kinase; E2F1: E2F transcription factor } \\
\text { 1; CDK: cyclin-dependent kinase; Rb: retinoblastoma protein; DLG1: disks large homolog 1; hTERT: human } \\
\text { telomerase reverse transcriptase; BDNF: brain-derived neurotrophic factor; TrkB: tropomyosin receptor kinase } \\
\text { B; PCNA: proliferating cell nuclear antigen; Wnt5a: Wingless-Type MMTV Integration Site Family, Member 5A; } \\
\text { CENP-B: centromere protein B; FOXP3: forkhead box P3; BIM: Bcl2-interacting mediator of cell death; FOXO3a: } \\
\text { forkhead box O3a; DDR: DNA damage repair; MDC1: mediator of DNA damage checkpoint protein 1; IFN } \gamma \text { : } \\
\text { interferon gamma; CHK1: checkpoint kinase 1; CHK2: checkpoint kinase 2; APC/C: anaphase-promoting } \\
\text { complex/cyclosome; TIGIT: T-cell receptor with immunoglobulin and ITIM domains; RANBP1: Ran-specific } \\
\text { binding protein 1. }\end{array}$} \\
\hline
\end{tabular}




\subsection{Tax Hijacks Key Mediators of DNA Damage Repair to Activate TAK1, IKK/NF-кB, and Other Kinases}

Polyubiquitin chain assembly is a post-translational modification by which protein-linked or unanchored polyubiquitin chains are assembled stepwise via three classes of enzymes, ubiquitin E1 activating enzymes, E2 conjugating enzymes, and E3 ligases. Lysine 48 (K48)-linked polyubiquitin targets proteins for proteasome-mediated degradation, while lysine 63 (K63)-linked and linear polyubiquitins are crucial in regulating a variety of cellular processes including cytokine-mediated IKK/NF-KB activation, DDR signaling, and cytokinesis [103-105]. Advances over the past decade have demonstrated that upon T- or B-cell receptor engagement, or stimulation by cytokines such as tumor necrosis factor alpha (TNF $\alpha$ ) and interleukin-1 (IL-1), or pathogen-associated molecules such as bacterial lipopolysaccharide (LPS), members of the TNF receptor-associated factor (TRAF) family such as TRAF6, TRAF2 $/ 5$, and cIAP1/2 become recruited to the receptors and interact with ubiquitin E2 conjugating enzymes, UBC13:Uev1a/Uev2, to assemble free or protein-anchored K63-linked polyubiquitin (K63-pUb) chains (reviewed in [106]). The IKK kinase, transforming growth factor beta (TGF $\beta$ )-activated kinase 1 (TAK1), and IKK both contain ubiquitin-binding subunits (TAK1-binding protein $2 / 3$ (TAB2/3) and NF- $\mathrm{KB}$ essential modulator (NEMO), respectively) that facilitate their recruitment to K63-pUb chains where TAK1 undergoes auto-phosphorylation/activation [106]. Activated TAK1 then phosphorylates and activates IKK in its vicinity. IKK in turn phosphorylates IKB $\alpha$, targeting it for K48-linked polyubiquitination and proteasomal degradation, thereby activating the canonical NF-KB pathway. Interestingly, Ed Hahaj's lab has previously reported that conjugation of Tax by K63-pUb correlates with IKK activation, and requires the ubiquitin E2 conjugating enzyme UBC13 [107]. Indeed, mouse embryo fibroblasts containing bi-allelic deletion of the $u b c 13$ gene are deficient in supporting Tax-driven NF- $\mathrm{kB}$ activation [107]. Additional evidence implicating the importance of K63-pUb in Tax-dependent IKK/NF- $\mathrm{kB}$ activation came from in vitro assays showing that the K63R mutant of ubiquitin could inhibit IKK activation by Tax in cytosolic extract of Jurkat T-cells [108]. These results support the notion that K63-pUb assembly plays an important role in Tax-mediated IKK/NF- $\mathrm{BB}$ activation. Finally, using both cell-based assays and in vitro systems reconstituted from purified proteins, we have demonstrated that Tax hijacks and aberrantly activates the ubiquitin E3 ligase, RNF8, and its associated E2 conjugating enzymes, UBC13:Uev1a/Uev2 - transducers of DSB repair signaling and cytokinesis regulation-to assemble $\mathrm{K} 63-\mathrm{pUb}$ chains for TAK1 and IKK/NF- $\mathrm{kB}$ activation [102]. These results indicate that IKK/NF- $\mathrm{KB}$ activation and DDR repression by Tax are likely connected via RNF8 (Figure 2A). It is conceivable that the hijacking of RNF8 by Tax and the ensuing over-production of misdirected K63-pUb chains result in a defect in DDR, thus driving the genomic instability in HTLV-1-infected T-cells.

A most recent report by Wang et al. suggests that Tax itself is a ubiquitin E3 ligase that, together with a group of $\mathrm{E} 2$ enzymes including $\mathrm{UBCH}$, UBCH5b, UBCH5c, and UBCH2, assembles mixed-linkage polyubiquitin chains for IKK activation in a UBC13- and TAK1-independent manner [109]. This conclusion contrasts with published results from multiple laboratories showing the importance of TAK1 and UBC13 in Tax-driven NF-KB activation [102,107,108,110-112]. As mentioned above, Shibata et al. have previously shown that K63R and $\mathrm{K} 0$ mutants of ubiquitin block IKK activation by Tax in cell-free assays and concluded that the assembly of K63-pUb chains is crucial for Tax-mediated IKK activation [108]. This is the simplest interpretation of the data, and is in line with published literature $[102,107,108,110-112]$ and the well-established mechanism by which IKK is activated. While Wang et al. confirmed the same observation, they interpreted the data in a more complex model, suggesting that K63R-Ub is a less efficient substrate for the assembly of mixed-linkage polyubiquitin chains by Tax. It should be pointed out that no RING domain or HECT domain commonly found in E3 ligases can be discerned in Tax. Whether Tax belongs to an entirely new class of E3 ligases that utilize multiple E2s to assemble mixed-linkage polyubiquitin chains, as claimed, remains to be confirmed. 
A

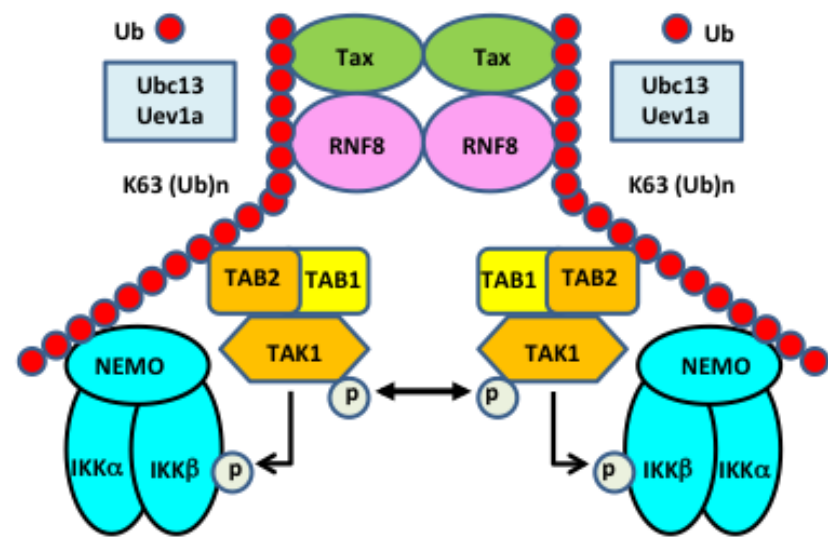

B

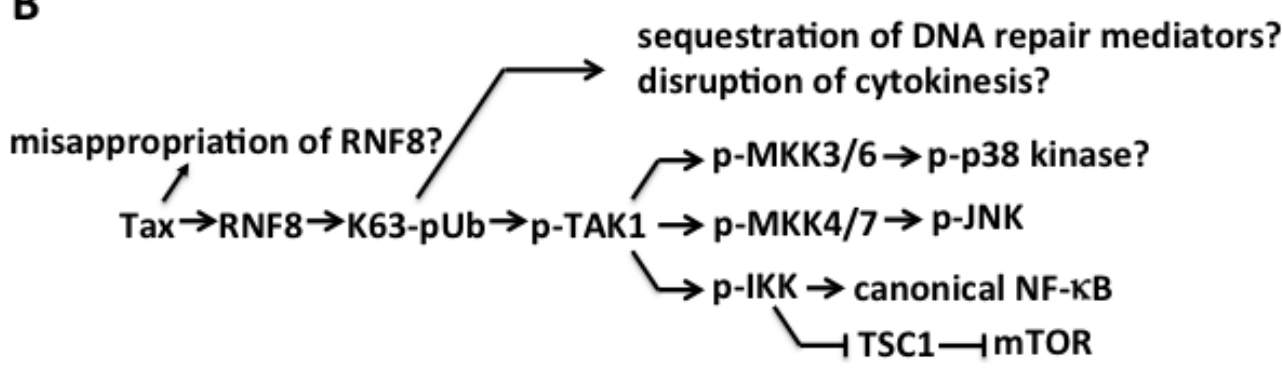

Figure 2. Tax hijacks the ubiquitin E3 ligase, ring finger protein 8 (RNF8) and E2 conjugating enzyme UBC13: Uev1A/Uev2 to activate transforming growth factor beta (TGF $\beta$ )-activated kinase 1 (TAK1), I kappa B kinase (IKK), canonical NF-KB and other signaling pathways. (A) Tax directly interacts with and stimulates RNF8 and Ubc13:Uev1A/2 to assemble long lysine 63-linked polyubiquitin (K63-pUb) chains, which then serve as the signaling scaffolds for K63-pUb-binding TAK1 and IKK to convene and become activated. As NF-KB essential modulator (NEMO) interacts weakly with $\mathrm{K} 63-\mathrm{pUb}$ chains, the direct interaction between Tax and NEMO may mediate IKK recruitment to and activation by TAK1. (B) The Tax-RNF8 signaling axis drives increased assembly of K63-linked polyubiquitin chains, which activate TAK1. TAK1, in turn, signals the activation of MKKs and IKK, and downstream p38 kinase, c-Jun N-terminal kinase (JNK), mammalian target of rapamycin (mTOR), and the canonical NF- $\mathrm{B}$ B pathway. The misappropriation and aberrant activation of RNF8 and the increased assembly of K63-linked polyubiquitin chains may sequester key mediators of DNA damage repair and cytokinesis to induce genomic instability in the forms of DNA double-strand breaks (DSBs) and chromosome aneuploidy.

Finally, RNF8, along with RNF168, are key mediators of the cellular response to DNA damage (for review see $[113,114])$. A hallmark feature of the cellular response to DSBs is the coordinated sequential formation of repair complexes into foci, the biogenesis and subsequent removal of which reflects repair efficiency. One of the early events in the formation of repair foci is ataxia telangiectasia mutated (ATM)-mediated phosphorylation of MDC1 and subsequent stabilization of repair complexes. RNF8 is recruited to sites of DSBs via interaction between its FHA domain and phosphorylated MDC1 [115]. The subsequent ubiquitination of local histones is required for assembly of p53-binding protein 1 (53BP1) and BRCA1 via K63-linked polyubiquitin chains and repair of DNA breaks [116]. RNF8 also ubiquitylates nibrin (Nbs1), a member of the Mre11/Rad50/Nbs1 (MRN) complex, to promote its binding to DSBs to facilitate repair via homologous recombination [117]. Underscoring the interplay between RNF8 and MDC1, subsequent degradation of MDC1 via sumoylation is a second critical determinant of homologous recombination [118]. Thus, it is likely that the competitive recruitment of MDC1 away from DNA damage foci is mediated through the sequestration or aberrant activation of RNF8 by Tax. 


\subsection{The Pleiotropic Effect of Tax on Cell Signaling Explained?}

Tax potently and specifically activates viral transcription by binding the basic domains of CREB/ATF-1 and contacting the G/C-rich sequences flanking the viral cAMP response elements in the Tax-responsive 21-bp repeat enhancer to form a ternary Tax:CREB/ATF-1:21-bp repeat nucleoprotein complex. In this ternary complex, Tax further recruits transcriptional co-activators/histone acetylases, $\mathrm{CBP} / \mathrm{p} 300$ and p300/CBP-associated factor (P/CAF), and transducers of regulated CREB (TORCs) [119] to establish a nucleosome-free region for potent HTLV-1 viral mRNA transcription (reviewed in [120]).

Tax is notorious for exerting pleiotropic influence on cell signaling. It activates both the canonical and non-canonical NF- $\mathrm{KB}$ pathways, the transcriptional activities of activator protein 1 (AP1), the serum response factor (SRF), and the NFAT, and the kinase activity of the mTOR, etc. [3]. Because of the many roles K63-pUb and TAK1 play in cell signaling, the hijacking and inappropriate activation of RNF8 by Tax and the resultant over-production of K63-pUb chains may provide a simple explanation for many of the biological effects of Tax (summarized in Figure 2B and Table 1). Indeed, the activation of JNK phosphorylation by Tax and RNF8 in vitro (via TAK1 and presumably the mitogen-activated protein kinase kinase MKK7) is consistent with earlier studies showing AP1 activation by Tax and JNK activation in HTLV-1-transformed cells [121]. Further, TAK1, IKK $\alpha$, and IKK $\beta$ each control multiple signaling pathways that are NF-KB-unrelated [122]. TAK1 is known to activate MKK3/6 and MKK4/7, which activate downstream $\mathrm{p} 38$ kinase and JNK, respectively. IKK $\beta$ can phosphorylate and inactivate the tuberous sclerosis 1 (TSC1) tumor suppressor complex [123] that represses the serine/threonine kinase, the mTOR, leading to mTOR activation [123]. The implied activation of AP1, SRF, NFAT, and mTOR by Tax via the Tax $\Rightarrow R N F 8 \Rightarrow K 63-p U b$ chains $\Rightarrow$ TAK1 signaling axis awaits further validation (Figure 2B).

A recent study has shown that, during IL-1 $\beta$ signaling, linear polyubiquitin assembled by a unique E3 ligase complex, known as linear ubiquitin assembly complex (LUBAC), consisting of HOIL-1-interacting protein (HOIP), heme-oxidized IRP2 ubiquitin ligase-1 (HOIL-1), and Shank-associated RH domain interactor (Sharpin), becomes covalently attached to K63-pUb to form K63/M1-hybrid pUb [124]. Because NEMO has 100-fold higher binding affinity for M1-pUb than for $\mathrm{K} 63-\mathrm{pUb}$, it is proposed that TAK1 and IKK, respectively, are recruited to K63-pUb and M1-pUb of the hybrid $\mathrm{pUb}$ such that signaling between these two kinases can occur. Tax is known to bind NEMO directly. It has been reported that the interaction between Tax and NEMO in cell-free extract is not affected by polyubiquitination [108]. Furthermore, the ubiquitin-binding defective mutants (D311N and L329P) of NEMO, while deficient in mediating NF- $\mathrm{kB}$ activation by TNF $\alpha$, continue to support Tax-mediated NF- $K B$ activation [110]. The direct interaction between Tax and NEMO may obviate the need for linear polyubiquitin in IKK recruitment to and activation by TAK1.

\subsection{HTLV-1, Tax, and Chromosome Instability}

Centrosomes, the microtubule organizing centers (MTOCs), are responsible for bipolar mitotic spindle formation and proper segregation of chromosomes during mitosis. Centrosome duplication occurs once in every cell division cycle (centrosome duplication "licensing") and is tightly regulated. Centrosome amplification can lead to multipolar spindle formation and unequal chromosome segregation. Tax has been shown to cause centrosome amplification or fragmentation. This has been hypothesized as a contributing factor to the development of aneuploidy in ATL cells. The mechanism underlying Tax-mediated centrosomal abnormality is not entirely resolved. Interaction between Tax and Ran-specific binding protein 1 (RanBP1) that results in a disruption of Ran-RanBP1 regulation of centriole cohesion has been proposed [125]. A role of NF- $\mathrm{KB}$ in Tax-mediated centrosomal amplification has also been suggested [125]. Rootletin (TaxBP121), a protein with extensive coiled-coil structure previously identified in yeast 2-hybrid screen as a Tax-binding partner, has been shown to inhibit centrosome duplication [126]. TaxBP121 knockdown or putative inactivation through interaction with Tax, leads to centrosome hyperamplification. Another model for Tax-induced chromosome 
instability (CIN) posits that a direct interaction between Tax and human homolog of MAD1 (HsMAD1), a critical component of the spindle checkpoint, causes spindle assembly checkpoint defect [127], which allows mitosis to proceed even though proper attachment of sister chromatids to the mitotic spindle is impaired, thus causing uneven distribution of chromosomes and aneuploidy. However, Tax-expressing HTLV-1-transformed T-cells arrest in metaphase after treatment with the microtubule-disrupting agent, nocodazole, suggesting that the spindle checkpoint defect caused by Tax is subtle, if it happens at all $[128,129]$. RNF8 has an established non-enzymatic role in the unfolding of chromatin to facilitate DDR factor recruitment to DSBs [130]. In addition, RNF8 targets septins for ubiquitination and localizes to centrosomes [131]. Interestingly, RNF8-mediated polyubiquitination regulates exit from mitosis, and over-expression of RNF8 resulted in a delay of mitotic exit, unresolved cytokinesis, and multinucleated cells [132]. Again, it is tempting to speculate that the Tax-NF8 nexus is responsible for the reported effects of HTLV-1 on chromosomal integrity and multinucleation. Which of these mechanisms eventually can account for the cytokinesis defects and chromosome aneuploidy associated with Tax awaits further investigations. Finally, the pX region of HTLV-1 genome has been shown to contain a binding site for the CCCTC-binding factor (CTCF), a cellular protein involved in organizing high-order chromatin structure [133]. CTCF binding to the viral binding site sharply defines the border of epigenetic modifications in proviral DNA and acts as an enhancer blocker [134]. Interestingly, CTCF binding also regulates HTLV-1 mRNA splicing and mediates interaction between CTCF-binding sites in HTLV-1 proviral DNA and adjacent chromosomal regions [134]. How the long-range interaction between viral and cellular CTCF-binding sites and the ensuing chromatin looping contribute to the regulation of the HTLV-1 replicative cycle and the genomic instability in ATL cells remains to be explored.

\section{HBZ and ATL Development}

\subsection{HBZ Gene Expression}

The HBZ gene is located at the $3^{\prime}$ end of the viral genome. HBZ RNA is synthesized from the minus or antisense strand of the viral genome, and is of the opposite polarity of the major HTLV-1 viral transcript. HBZ RNA exists in both spliced and unspliced forms. The sHBZ transcript is predominant in ATL cells, and it and its protein product are commonly referred to as HBZ. The protein product of the unspliced HBZ transcript is known as usHBZ. It is slightly larger than HBZ in size and contains a stretch of seven additional $\mathrm{NH}_{2}$-terminal amino acid residues, MVNFVSV. The usHBZ has a much shorter half-life compare to HBZ and is observed at lower concentrations in HTLV-1 infection. Tax has been found to up-regulate HBZ expression and this up-regulation is influenced by the HTLV-1 integration sites [135].

\subsection{HBZ RNA, HBZ, and usHBZ}

Both usHBZ and HBZ antagonize the activities of Tax at the levels of LTR trans-activation and NF- $k B$ activation [86]. However, HBZ can stimulate T-cell proliferation, while usHBZ cannot [24]. HBZ expression is regulated by three specificity protein 1 (SP1) binding sites in a TATA-less promoter located in the 3'-LTR of the proviral DNA [24]. Interestingly, both HBZ and HBZ RNA have been shown to promote T-cell proliferation [10]. Thus, three separate molecules: HBZ, HBZ RNA, and usHBZ encoded by the antisense strand of the HTLV-1 genome function to regulate viral gene expression and the proliferation and persistence of provirus-harboring T-cells. The roles of usHBZ in viral replication, persistence, and pathogenesis remain unclear.

\subsection{HBZ Antagonizes Many of the Activities of Tax}

For details of the domain organization and activities of HBZ, readers are referred to several excellent reviews $[5,136,137]$. HBZ is a basic domain leucine zipper protein. Via its leucine zipper domain, HBZ interacts with and disrupts the DNA-binding or transcriptional activities of CREB-2, JunB, 
and c-Jun (AP1). It also binds the KIX domain of CBP/p300 and inhibits its HAT activity, thus blocking Tax-driven viral mRNA expression. HBZ, however, interacts with JunD and activates JunD-mediated transcription. As mentioned above, HBZ down-regulates the nuclear export of full-length and singly spliced HTLV-1 mRNAs by Rex to inhibit the production Gag, Gag-Pol, and Env proteins. HBZ also dampens NF- $\mathrm{kB}$ activity by preventing NF- $\mathrm{KB}$ binding to DNA and inducing p65/RelA degradation, thus mitigating the cellular senescence response triggered by Tax-driven NF- $\kappa B$ hyperactivation. These activities of HBZ promote the establishment of latent HTLV-1 infection and facilitate the persistence of infected cells (Figure 1). A comparison between Tax and HBZ activities and functional consequences is shown in Table 1.

\subsection{HBZ Promotes T-Cell Proliferation}

Soon after ATL cells were found to persistently express HBZ, but not Tax, both HBZ RNA and protein were shown to stimulate T-cell proliferation. Recent data indicate that HBZ protein additionally promotes apoptosis induction, while HBZ mRNA prevents it, in part via up-regulation of the survivin gene [138]. Importantly, CD4+ T lymphocyte-specific expression of the HBZ transgene in mice induces T-cell lymphoma and systemic inflammation [8]. The HBZ transgene also directly stimulates the expression of Foxp3 in mouse CD4+ T-cells, thus providing an explanation for why ATL cells are often Foxp3+ [139]. The expression of HBZ in CD4+ T-cells shows a positive correlation with the expression of oncomiRs, which have been associated with a wide range of oncogenic activities [140]. HBZ protein also assists JunD in the transcriptional activation of human telomerase reverse transcriptase (hTERT) [141]. Recent results indicate that HBZ protein can target the retinoblastoma protein $(\mathrm{Rb}) /$ E2F transcription factor 1 (E2F1) complex to activate the transcription of genes under E2F1 control that are critical for DNA replication and cell cycle progression [138]. The activation of E2F-regulated genes by HBZ promotes both T-cell proliferation and apoptosis. These results clearly demonstrate the growth-promoting and oncogenic properties of HBZ, and explain why HBZ is persistently expressed in ATL cells. Finally, HBZ has been found to induce the expression of a co-inhibitory immune receptor molecule, T-cell receptor with immunoglobulin and ITIM domains (TIGIT), to facilitate IL-10 production, possibly to suppress antiviral immune responses [142].

\section{Concluding Remarks and Future Perspectives}

\subsection{The Balance between Tax and HBZ Regulates Viral Latency and Persistence}

It has become abundantly clear over the past few years that HTLV-1 has evolved a replicative strategy that is unique among retroviruses. By encoding HBZ and HBZ RNA from promoters extrinsic of the viral LTRs (thus allowing expression of genes that are largely independent from viral replication and Tax trans-activation), HTLV-1 succeeds in (a) down-regulating Tax/Rex-mediated viral gene expression and replication; (b) mitigating the senescence response triggered by hyperactivated NF-KB; (c) down-regulating cellular immune responses [142]; and (d) promoting proliferation and survival of infected T-cells. These activities of HBZ and HBZ RNA facilitate evasion from immune detection and drive the persistence and expansion of "latently" HTLV-1-infected cells. The immortalization/transformation of T-cells by HTLV-1 that gives rise to T-cell lines such as MT2, MT4, and C8166 that express Tax at high levels occurs rarely, and most likely requires specific cellular changes that inactivate the senescence response induced by Tax (Figure 3). 
Loss of senescence response activating mutations in PLCG1, VAV1, PKCB? p21/p27 inactivation or down-regulation Down-regulation of NF-KB activation RNF8 loss or repression? Foxp3 expression?
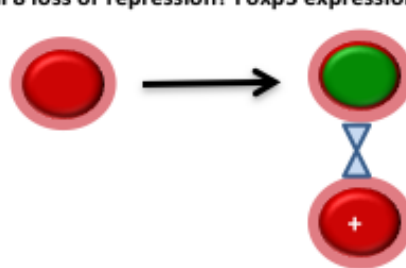

HTLV-1 infection of "abnormal" T cells

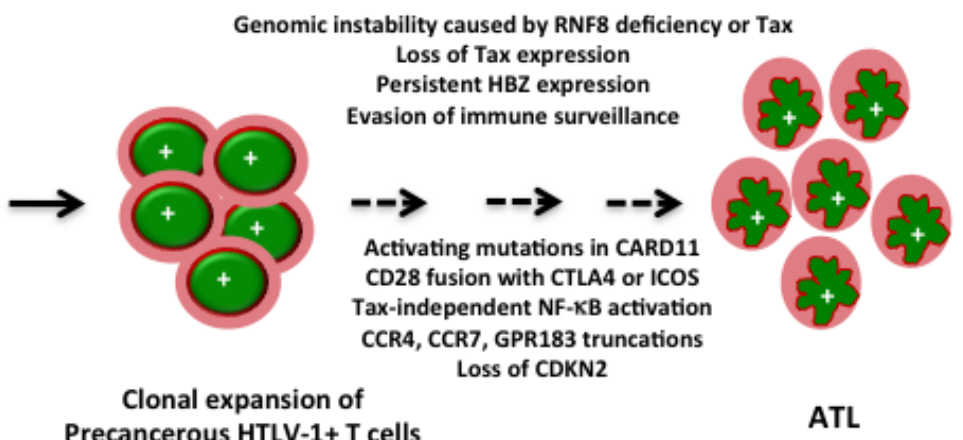

Precancerous HTLV-1+ T cells

Figure 3. A model for adult T-cell leukemia/lymphoma (ATL) development. Loss of senescence response and/or inhibition or down-regulation of NF- $k B$ activation (cells marked with green nuclei) drives clonal expansion of HTLV-1-infected cells (each marked with a "+" sign). Some of these cells, presumably precancerous, continue to evolve, propelled by the genomic instability caused by either Tax or the loss of RNF8, eventually giving rise to ATL. The frequent genetic alterations detected in ATLs, such as activating point mutations in phospholipase $C \gamma 1$ (PLCG1), vav guanine nucleotide exchange factor 1 (VAV1), and protein kinase $\mathrm{C} \beta$ (PKCB), activating point mutations and deletions in caspase recruitment domain-containing protein 11 (CARD11), CTLA4/CD152-CD28, and inducible T-cell COStimulator (ICOS)/CD278-CD28 fusions, homozygous deletion of cyclin-dependent kinase inhibitor 2A (CDKN2), and chemokine (C-C motif) receptor 4 (CCR4), CCR7, and G protein-coupled receptor 183 (GPR183) truncations, are incorporated into this model to stimulate discussions and suggest future experiments.

\subsection{The Indispensable Role of Tax and HBZ in ATL Development}

With the ubiquitous expression of HBZ in ATL cells and the many roles of HBZ in viral persistence, growth stimulation, and tumor development firmly established, it would appear that Tax should relegate its title as the HTLV-1 viral oncogene. A critical review of the most current literature, however, indicates otherwise: Two of the most striking features of ATL revealed by the whole genome sequence analysis [6] are connected to Tax: (1) the extensive genomic instability of ATL; and (2) the functional overlap between the pathways and molecules that Tax is known to activate (Figure $2 \mathrm{~B}$ ) and the genetic alterations in ATLs, which converge on signaling molecules in the TCR-NF-KB and the CD-28 co-stimulatory pathways (Figure 3).

The hijacking and aberrant activation of RNF8 not only explains the pleiotropic effect of Tax on cell signaling (e.g., activation of TAK1, IKK/canonical NF-KB, and JNK), but likely can also account for the genomic instability induced by Tax (Figure 2B). Evidence in support of this hypothesis should be forthcoming. Based on current information, senescence induction by HTLV-1 can be lessened through the inactivation of the cellular mediators of the senescence response (p21 and p27) or the inhibition of NF-KB activation (Figure 3). One can easily imagine that during the course of HTLV-1 persistence, viral infection may accidentally take place in T-cells whose senescence mediators become inactivated, e.g., via activating mutations in PLCG1, PKCB, VAV1, or FYN that frequently recur in ATL [6] (Figure 3). Of note, VAV1 lies upstream of PLCG1 and PI3K and its activation causes the phosphorylation and inactivation of forkhead box protein $\mathrm{O} 1$ (FOXO1) - a transcription factor critical for p27 expression - to down-regulate p27 and promote T-cell proliferation [143]. It is conceivable that, with activating VAV1 mutations, HTLV-1 infection and significant Tax expression can occur without triggering an overt senescence response. The direct dysregulation of RNF8 by Tax can then promote genomic instability by causing a deficit in DSBs repair (Figure $2 \mathrm{~B}$ ). Since activating mutations in PLCG1 and PKCB also promote NF- $\mathrm{BB}$ activation, they may supplant many of the functions of Tax to facilitate the eventual silencing of Tax expression (Figure 3). When Tax expression becomes silenced during ATL development, the loss of senescence mediators could facilitate the development of Tax-independent NF- $\mathrm{kB}$ activation via CARD-11 mutations (Figure 3). In another 
scenario, clonal expansion of HTLV-1-infected T-cells may be facilitated by RNF8 down-regulation (which moderates TAK1 and NF- $\mathrm{KB}$ hyperactivation and is expected to dampen senescence induction). After Tax expression is silenced or lost, the down-regulation of RNF8 is expected to continue to cause genomic instability in cells that are propelled to proliferate by HBZ. In this vein, many of the genetic alterations such as chemokine (C-C motif) receptor 4 (CCR4), CCR7, and G protein-coupled receptor 183 (GPR183) truncations, intragenic deletions in CARD11, and gene rearrangements such as CTLA4/CD152-CD28 and and inducible T-cell COStimulator (ICOS)/CD278-CD28 fusions [6], may very well be the consequences of the genomic instability directly or indirectly induced by Tax. These scenarios are not mutually exclusive and may occur at different stages of HTLV-1 infection and disease progression. Finally, the Tax/RNF8-related genomic instability and the senescence-escaping activating mutations may prove to be the Achilles' heel that can be exploited and targeted to develop effective treatment approaches for ATL.

Author Contributions: C.-Z.G. and O.J.S. wrote and approved the manuscript.

Conflicts of Interest: The authors declare no conflict of interest.

\section{References}

1. Gessain, A.; Cassar, O. Epidemiological aspects and world distribution of HTLV-1 infection. Front. Microbiol. 2012, 3, 388. [CrossRef] [PubMed]

2. Taylor, G.P.; Matsuoka, M. Natural history of adult T-cell leukemia/lymphoma and approaches to therapy. Oncogene 2005, 24, 6047-6057. [CrossRef] [PubMed]

3. Matsuoka, M.; Jeang, K.T. Human T-cell leukaemia virus type 1 (HTLV-1) infectivity and cellular transformation. Nat. Rev. Cancer 2007, 7, 270-280. [CrossRef] [PubMed]

4. Tsukasaki, K.; Hermine, O.; Bazarbachi, A.; Ratner, L.; Ramos, J.C.; Harrington, W., Jr.; O’Mahony, D.; Janik, J.E.; Bittencourt, A.L.; Taylor, G.P.; et al. Definition, prognostic factors, treatment, and response criteria of adult T-cell leukemia-lymphoma: A proposal from an international consensus meeting. J. Clin. Oncol. 2009, 27, 453-459. [CrossRef] [PubMed]

5. Matsuoka, M.; Green, P.L. The HBZ gene, a key player in HTLV-1 pathogenesis. Retrovirology 2009, 6, 71. [CrossRef] [PubMed]

6. Kataoka, K.; Nagata, Y.; Kitanaka, A.; Shiraishi, Y.; Shimamura, T.; Yasunaga, J.; Totoki, Y.; Chiba, K.; Sato-Otsubo, A.; Nagae, G.; et al. Integrated molecular analysis of adult T cell leukemia/lymphoma. Nat. Genet. 2015, 47, 1304-1315. [CrossRef] [PubMed]

7. Satou, Y.; Yasunaga, J.; Yoshida, M.; Matsuoka, M. HTLV-1 BZIP factor (HBZ) gene has a growth-promoting effect on adult T-cell leukemia cells. Rinsho Ketsueki 2008, 49, 1525-1529. [PubMed]

8. Satou, Y.; Yasunaga, J.; Zhao, T.; Yoshida, M.; Miyazato, P.; Takai, K.; Shimizu, K.; Ohshima, K.; Green, P.L.; Ohkura, N.; et al. HTLV-1 BZIP factor induces T-cell lymphoma and systemic inflammation in vivo. PLoS Pathog. 2011, 7, e1001274. [CrossRef] [PubMed]

9. Arnold, J.; Zimmerman, B.; Li, M.; Lairmore, M.D.; Green, P.L. Human T-cell leukemia virus type-1 antisense-encoded gene, HBZ, promotes T-lymphocyte proliferation. Blood 2008, 112, 3788-3797. [CrossRef] [PubMed]

10. Satou, Y.; Yasunaga, J.; Yoshida, M.; Matsuoka, M. HTLV-I basic leucine zipper factor gene mRNA supports proliferation of adult T cell leukemia cells. Proc. Natl. Acad. Sci. USA 2006, 103, 720-725. [CrossRef] [PubMed]

11. Chapman, M.A.; Lawrence, M.S.; Keats, J.J.; Cibulskis, K.; Sougnez, C.; Schinzel, A.C.; Harview, C.L.; Brunet, J.P.; Ahmann, G.J.; Adli, M.; et al. Initial genome sequencing and analysis of multiple myeloma. Nature 2011, 471, 467-472. [CrossRef] [PubMed]

12. Marriott, S.J.; Semmes, O.J. Impact of HTLV-I Tax on cell cycle progression and the cellular DNA damage repair response. Oncogene 2005, 24, 5986-5995. [CrossRef] [PubMed]

13. Majone, F.; Semmes, O.J.; Jeang, K.T. Induction of micronuclei by HTLV-I Tax: A cellular assay for function. Virology 1993, 193, 456-459. [CrossRef] [PubMed]

14. Majone, F.; Jeang, K.T. Clastogenic effect of the human T-cell leukemia virus type I Tax oncoprotein correlates with unstabilized DNA breaks. J. Biol. Chem. 2000, 275, 32906-32910. [CrossRef] [PubMed] 
15. Semmes, O.J.; Majone, F.; Cantemir, C.; Turchetto, L.; Hjelle, B.; Jeang, K.T. HTLV-I and HTLV-II Tax: Differences in induction of micronuclei in cells and transcriptional activation of viral LTRS. Virology 1996, 217, 373-379. [CrossRef] [PubMed]

16. Edwards, D.; Fenizia, C.; Gold, H.; de Castro-Amarante, M.F.; Buchmann, C.; Pise-Masison, C.A.; Franchini, G. ORF-I and ORF-II-encoded proteins in HTLV-1 infection and persistence. Viruses 2011, 3, 861-885. [CrossRef] [PubMed]

17. Banerjee, P.; Feuer, G.; Barker, E. Human T-cell leukemia virus type 1 (HTLV-1) p12I down-modulates ICAM-1 and -2 and reduces adherence of natural killer cells, thereby protecting HTLV-1-infected primary CD4+ T cells from autologous natural killer cell-mediated cytotoxicity despite the reduction of major histocompatibility complex class I molecules on infected cells. J. Virol. 2007, 81, 9707-9717. [PubMed]

18. Pise-Masison, C.A.; de Castro-Amarante, M.F.; Enose-Akahata, Y.; Buchmann, R.C.; Fenizia, C.; Washington Parks, R.; Edwards, D.; Fiocchi, M.; Alcantara, L.C., Jr.; Bialuk, I.; et al. Co-dependence of HTLV-1 p12 and p8 functions in virus persistence. PLoS Pathog. 2014, 10, e1004454. [CrossRef] [PubMed]

19. Hiraragi, H.; Michael, B.; Nair, A.; Silic-Benussi, M.; Ciminale, V.; Lairmore, M. Human T-lymphotropic virus type 1 mitochondrion-localizing protein P13II sensitizes jurkat T cells to ras-mediated apoptosis. J. Virol. 2005, 79, 9449-9457. [CrossRef] [PubMed]

20. Andresen, V.; Pise-Masison, C.A.; Sinha-Datta, U.; Bellon, M.; Valeri, V.; Washington Parks, R.; Cecchinato, V.; Fukumoto, R.; Nicot, C.; Franchini, G. Suppression of HTLV-1 replication by Tax-mediated rerouting of the p13 viral protein to nuclear speckles. Blood 2011, 118, 1549-1559. [CrossRef] [PubMed]

21. Lefebvre, L.; Vanderplasschen, A.; Ciminale, V.; Heremans, H.; Dangoisse, O.; Jauniaux, J.C.; Toussaint, J.F.; Zelnik, V.; Burny, A.; Kettmann, R.; et al. Oncoviral bovine leukemia virus G4 and human T-cell leukemia virus type 1 p13(II) accessory proteins interact with farnesyl pyrophosphate synthetase. J. Virol. 2002, 76, 1400-1414. [CrossRef] [PubMed]

22. Silic-Benussi, M.; Cavallari, I.; Zorzan, T.; Rossi, E.; Hiraragi, H.; Rosato, A.; Horie, K.; Saggioro, D.; Lairmore, M.D.; Willems, L.; et al. Suppression of tumor growth and cell proliferation by p13II, a mitochondrial protein of human T cell leukemia virus type 1. Proc. Natl. Acad. Sci. USA 2004, 101, 6629-6634. [CrossRef] [PubMed]

23. Nicot, C.; Dundr, M.; Johnson, J.M.; Fullen, J.R.; Alonzo, N.; Fukumoto, R.; Princler, G.L.; Derse, D.; Misteli, T.; Franchini, G. HTLV-1-encoded p30II is a post-transcriptional negative regulator of viral replication. Nat. Med. 2004, 10, 197-201. [CrossRef] [PubMed]

24. Yoshida, M.; Satou, Y.; Yasunaga, J.; Fujisawa, J.; Matsuoka, M. Transcriptional control of spliced and unspliced human T-cell leukemia virus type 1 BZIP factor (HBZ) gene. J. Virol. 2008, 82, 9359-9368. [CrossRef] [PubMed]

25. Manel, N.; Kim, F.J.; Kinet, S.; Taylor, N.; Sitbon, M.; Battini, J.L. The ubiquitous glucose transporter glut-1 is a receptor for HTLV. Cell 2003, 115, 449-459. [CrossRef]

26. Lambert, S.; Bouttier, M.; Vassy, R.; Seigneuret, M.; Petrow-Sadowski, C.; Janvier, S.; Heveker, N.; Ruscetti, F.W.; Perret, G.; Jones, K.S.; et al. HTLV-1 uses HSPG and neuropilin-1 for entry by molecular mimicry of VEGF165. Blood 2009, 113, 5176-5185. [CrossRef] [PubMed]

27. Jones, K.S.; Petrow-Sadowski, C.; Bertolette, D.C.; Huang, Y.; Ruscetti, F.W. Heparan sulfate proteoglycans mediate attachment and entry of human T-cell leukemia virus type 1 virions into CD4+ T cells. J. Virol. 2005, 79, 12692-12702. [CrossRef] [PubMed]

28. Igakura, T.; Stinchcombe, J.C.; Goon, P.K.; Taylor, G.P.; Weber, J.N.; Griffiths, G.M.; Tanaka, Y.; Osame, M.; Bangham, C.R. Spread of HTLV-I between lymphocytes by virus-induced polarization of the cytoskeleton. Science 2003, 299, 1713-1716. [CrossRef] [PubMed]

29. Barnard, A.L.; Igakura, T.; Tanaka, Y.; Taylor, G.P.; Bangham, C.R. Engagement of specific T-cell surface molecules regulates cytoskeletal polarization in HTLV-1-infected lymphocytes. Blood 2005, 106, 988-995. [CrossRef] [PubMed]

30. Derse, D.; Hill, S.A.; Lloyd, P.A.; Chung, H.; Morse, B.A. Examining human T-lymphotropic virus type 1 infection and replication by cell-free infection with recombinant virus vectors. J. Virol. 2001, 75, 8461-8468. [CrossRef] [PubMed]

31. Mazurov, D.; Ilinskaya, A.; Heidecker, G.; Lloyd, P.; Derse, D. Quantitative comparison of HTLV-1 and hiv-1 cell-to-cell infection with new replication dependent vectors. PLoS Pathog. 2010, 6, e1000788. [CrossRef] [PubMed] 
32. Nejmeddine, M.; Barnard, A.L.; Tanaka, Y.; Taylor, G.P.; Bangham, C.R. Human T-lymphotropic virus, type 1, tax protein triggers microtubule reorientation in the virological synapse. J. Biol. Chem. 2005, 280, 29653-29660. [CrossRef] [PubMed]

33. Nejmeddine, M.; Negi, V.S.; Mukherjee, S.; Tanaka, Y.; Orth, K.; Taylor, G.P.; Bangham, C.R. HTLV-1-Tax and ICAM-1 act on T-cell signal pathways to polarize the microtubule-organizing center at the virological synapse. Blood 2009, 114, 1016-1025. [CrossRef] [PubMed]

34. Jones, K.S.; Petrow-Sadowski, C.; Huang, Y.K.; Bertolette, D.C.; Ruscetti, F.W. Cell-free HTLV-1 infects dendritic cells leading to transmission and transformation of CD4(+) T cells. Nat. Med. 2008, 14, 429-436. [CrossRef] [PubMed]

35. Jain, P.; Manuel, S.L.; Khan, Z.K.; Ahuja, J.; Quann, K.; Wigdahl, B. DC-SIGN mediates cell-free infection and transmission of human T-cell lymphotropic virus type 1 by dendritic cells. J. Virol. 2009, 83, 10908-10921. [CrossRef] [PubMed]

36. De Castro-Amarante, M.F.; Pise-Masison, C.A.; McKinnon, K.; Washington Parks, R.; Galli, V.; Omsland, M.; Andresen, V.; Massoud, R.; Brunetto, G.; Caruso, B.; et al. Human T cell leukemia virus type 1 infection of the three monocyte subsets contributes to viral burden in humans. J. Virol. 2015, 90, 2195-2207. [CrossRef] [PubMed]

37. Gross, C.; Thoma-Kress, A.K. Molecular mechanisms of HTLV-1 cell-to-cell transmission. Viruses 2016, 8, 74. [CrossRef] [PubMed]

38. Pais-Correia, A.M.; Sachse, M.; Guadagnini, S.; Robbiati, V.; Lasserre, R.; Gessain, A.; Gout, O.; Alcover, A.; Thoulouze, M.I. Biofilm-like extracellular viral assemblies mediate HTLV-1 cell-to-cell transmission at virological synapses. Nat. Med. 2010, 16, 83-89. [CrossRef] [PubMed]

39. Jaworski, E.; Narayanan, A.; Van Duyne, R.; Shabbeer-Meyering, S.; Iordanskiy, S.; Saifuddin, M.; Das, R.; Afonso, P.V.; Sampey, G.C.; Chung, M.; et al. Human T-lymphotropic virus type 1-infected cells secrete exosomes that contain Tax protein. J. Biol. Chem. 2014, 289, 22284-22305. [CrossRef] [PubMed]

40. Van Dooren, S.; Pybus, O.G.; Salemi, M.; Liu, H.F.; Goubau, P.; Remondegui, C.; Talarmin, A.; Gotuzzo, E.; Alcantara, L.C.; Galvao-Castro, B.; et al. The low evolutionary rate of human T-cell lymphotropic virus type-1 confirmed by analysis of vertical transmission chains. Mol. Biol. Evol. 2004, 21, 603-611. [CrossRef] [PubMed]

41. Asquith, B.; Hanon, E.; Taylor, G.P.; Bangham, C.R. Is human T-cell lymphotropic virus type I really silent? Philos. Trans. R. Soc. Lond. B Biol. Sci. 2000, 355, 1013-1019. [CrossRef] [PubMed]

42. Bangham, C.R.; Osame, M. Cellular immune response to HTLV-1. Oncogene 2005, 24, 6035-6046. [CrossRef] [PubMed]

43. Hanon, E.; Hall, S.; Taylor, G.P.; Saito, M.; Davis, R.; Tanaka, Y.; Usuku, K.; Osame, M.; Weber, J.N.; Bangham CR, L.H. Abundant tax protein expression in CD4+ T cells infected with human T-cell lymphotropic virus type I (HTLV-I) is prevented by cytotoxic T lymphocytes. Blood 2000, 15, 1386-1392.

44. Tanaka, G.; Okayama, A.; Watanabe, T.; Aizawa, S.; Stuver, S.; Mueller, N.; Hsieh, C.C.; Tsubouchi, H. The clonal expansion of human $\mathrm{T}$ lymphotropic virus type 1-infected $\mathrm{T}$ cells: A comparison between seroconverters and long-term carriers. J. Infect. Dis. 2005, 191, 1140-1147. [CrossRef] [PubMed]

45. Okayama, A.; Stuver, S.; Matsuoka, M.; Ishizaki, J.; Tanaka, G.; Kubuki, Y.; Mueller, N.; Hsieh, C.C.; Tachibana, N.; Tsubouchi, H. Role of HTLV-1 proviral DNA load and clonality in the development of adult T-cell leukemia/lymphoma in asymptomatic carriers. Int. J. Cancer 2004, 110, 621-625. [CrossRef] [PubMed]

46. Umeki, K.; Hisada, M.; Maloney, E.M.; Hanchard, B.; Okayama, A. Proviral loads and clonal expansion of HTLV-1-infected cells following vertical transmission: A 10-year follow-up of children in Jamaica. Intervirology 2009, 52, 115-122. [CrossRef] [PubMed]

47. Niederer, H.A.; Bangham, C.R. Integration site and clonal expansion in human chronic retroviral infection and gene therapy. Viruses 2014, 6, 4140-4164. [CrossRef] [PubMed]

48. Cook, L.B.; Rowan, A.G.; Melamed, A.; Taylor, G.P.; Bangham, C.R. HTLV-1-infected T cells contain a single integrated provirus in natural infection. Blood 2012, 120, 3488-3490. [CrossRef] [PubMed]

49. Cook, L.B.; Melamed, A.; Niederer, H.; Valganon, M.; Laydon, D.; Foroni, L.; Taylor, G.P.; Matsuoka, M.; Bangham, C.R. The role of HTLV-1 clonality, proviral structure, and genomic integration site in adult T-cell leukemia/lymphoma. Blood 2014, 123, 3925-3931. [CrossRef] [PubMed] 
50. Derse, D.; Crise, B.; Li, Y.; Princler, G.; Lum, N.; Stewart, C.; McGrath, C.F.; Hughes, S.H.; Munroe, D.J.; $\mathrm{Wu}, \mathrm{X}$. Human T-cell leukemia virus type 1 integration target sites in the human genome: Comparison with those of other retroviruses. J. Virol. 2007, 81, 6731-6741. [CrossRef] [PubMed]

51. Meekings, K.N.; Leipzig, J.; Bushman, F.D.; Taylor, G.P.; Bangham, C.R. HTLV-1 integration into transcriptionally active genomic regions is associated with proviral expression and with HAM/TSP. PLoS Pathog. 2008, 4, e1000027. [CrossRef] [PubMed]

52. Takeda, S.; Maeda, M.; Morikawa, S.; Taniguchi, Y.; Yasunaga, J.; Nosaka, K.; Tanaka, Y.; Matsuoka, M. Genetic and epigenetic inactivation of tax gene in adult T-cell leukemia cells. Int. J. Cancer 2004, 109, 559-567. [CrossRef] [PubMed]

53. Taniguchi, Y.; Nosaka, K.; Yasunaga, J.; Maeda, M.; Mueller, N.; Okayama, A.; Matsuoka, M. Silencing of human T-cell leukemia virus type I gene transcription by epigenetic mechanisms. Retrovirology 2005, 2, 64. [CrossRef] [PubMed]

54. Liu, M.; Yang, L.; Zhang, L.; Liu, B.; Merling, R.; Xia, Z.; Giam, C.Z. Human T-cell leukemia virus type 1 infection leads to arrest in the G1 phase of the cell cycle. J. Virol. 2008, 82, 8442-8455. [CrossRef] [PubMed]

55. Philip, S.; Zahoor, M.A.; Zhi, H.; Ho, Y.K.; Giam, C.Z. Regulation of human T-lymphotropic virus type I latency and reactivation by HBZ and Rex. PLoS Pathog. 2014, 10, e1004040. [CrossRef] [PubMed]

56. Kuo, Y.L.; Giam, C.Z. Activation of the anaphase promoting complex by HTLV-1 tax leads to senescence. EMBO J. 2006, 25, 1741-1752. [CrossRef] [PubMed]

57. Zhi, H.; Yang, L.; Kuo, Y.L.; Ho, Y.K.; Shih, H.M.; Giam, C.Z. NF-kB hyper-activation by HTLV-1 tax induces cellular senescence, but can be alleviated by the viral anti-sense protein HBZ. PLoS Pathog. 2011, 7, e1002025. [CrossRef] [PubMed]

58. Anderson, M.D.; Ye, J.; Xie, L.; Green, P.L. Transformation studies with a human T-cell leukemia virus type 1 molecular clone. J. Virol. Methods 2004, 116, 195-202. [CrossRef] [PubMed]

59. Derse, D.; Heidecker, G.; Mitchell, M.; Hill, S.; Lloyd, P.; Princler, G. Infectious transmission and replication of human T-cell leukemia virus type 1. Front. Biosci. 2004, 9, 2495-2499. [CrossRef] [PubMed]

60. Hasegawa, H.; Sawa, H.; Lewis, M.J.; Orba, Y.; Sheehy, N.; Yamamoto, Y.; Ichinohe, T.; Tsunetsugu-Yokota, Y.; Katano, H.; Takahashi, H.; et al. Thymus-derived leukemia-lymphoma in mice transgenic for the Tax gene of human T-lymphotropic virus type I. Nat. Med. 2006, 12, 466-472. [CrossRef] [PubMed]

61. Nerenberg, M.; Hinrichs, S.H.; Reynolds, R.K.; Khoury, G.; Jay, G. The tat gene of human T-lymphotropic virus type 1 induces mesenchymal tumors in transgenic mice. Science 1987, 237, 1324-1329. [CrossRef] [PubMed]

62. Grossman, W.J.; Kimata, J.T.; Wong, F.H.; Zutter, M.; Ley, T.J.; Ratner, L. Development of leukemia in mice transgenic for the tax gene of human T-cell leukemia virus type I. Proc. Natl. Acad. Sci. USA. 1995, 92, 1057-1061. [CrossRef] [PubMed]

63. Yamaoka, S.; Tobe, T.; Hatanaka, M. Tax protein of human T-cell leukemia virus type I is required for maintenance of the transformed phenotype. Oncogene 1992, 7, 433-437. [PubMed]

64. Panfil, A.R.; Al-Saleem, J.J.; Green, P.L. Animal models utilized in HTLV-1 research. Virology 2013, 4, 49-59. [PubMed]

65. Dodon, M.D.; Villaudy, J.; Gazzolo, L.; Haines, R.; Lairmore, M. What we are learning on HTLV-1 pathogenesis from animal models. Front. Microbiol. 2012, 3, 320. [CrossRef] [PubMed]

66. Li, M.; Kesic, M.; Yin, H.; Yu, L.; Green, P.L. Kinetic analysis of human T-cell leukemia virus type 1 gene expression in cell culture and infected animals. J. Virol. 2009, 83, 3788-3797. [CrossRef] [PubMed]

67. Pozzatti, R.; Vogel, J.; Jay, G. The human T-lymphotropic virus type I tax gene can cooperate with the ras oncogene to induce neoplastic transformation of cells. Mol. Cell Biol. 1990, 10, 413-417. [CrossRef] [PubMed]

68. Semmes, O.J.; Barret, J.F.; Dang, C.V.; Jeang, K.T. Human T-cell leukemia virus type I Tax masks c-Myc function through a cAMP-dependent pathway. J. Biol. Chem. 1996, 271, 9730-9738. [PubMed]

69. Zahoor, M.A.; Philip, S.; Zhi, H.; Giam, C.Z. NF-кB inhibition facilitates the establishment of cell lines that chronically produce human T-lymphotropic virus type 1 viral particles. J. Virol. 2014, 88, 3496-3504. [CrossRef] [PubMed]

70. Tripp, A.; Banerjee, P.; Sieburg, M.; Planelles, V.; Li, F.; Feuer, G. Induction of cell cycle arrest by human T-cell lymphotropic virus type 1 Tax in hematopoietic progenitor (CD34+) cells: Modulation of p21cip1/waf1 and p27kip1 expression. J. Virol. 2005, 79, 14069-14078. [CrossRef] [PubMed] 
71. De La Fuente, C.; Santiago, F.; Chong, S.Y.; Deng, L.; Mayhood, T.; Fu, P.; Stein, D.; Denny, T.; Coffman, F.; Azimi, N.; et al. Overexpression of p21(waf1) in human T-cell lymphotropic virus type 1-infected cells and its association with cyclin A/cdk2. J. Virol. 2000, 74, 7270-7283. [CrossRef] [PubMed]

72. Zhang, L.; Zhi, H.; Liu, M.; Kuo, Y.L.; Giam, C.Z. Induction of p21(CIP1/WAF1) expression by human T-lymphotropic virus type 1 Tax requires transcriptional activation and mrna stabilization. Retrovirology 2009, 6, 35. [CrossRef] [PubMed]

73. Cereseto, A.; Washington, P.R.; Rivadeneira, E.; Franchini, G. Limiting amounts of p27kip1 correlates with constitutive activation of cyclin E-CDK2 complex in HTLV-I-transformed T-cells. Oncogene 1999, 18, 2441-2450. [CrossRef] [PubMed]

74. Chlichlia, K.; Moldenhauer, G.; Daniel, P.T.; Busslinger, M.; Gazzolo, L.; Schirrmacher, V.; Khazaie, K. Immediate effects of reversible HTLV-1 tax function: T-cell activation and apoptosis. Oncogene 1995, 10, 269-277. [PubMed]

75. Hall, A.P.; Irvine, J.; Blyth, K.; Cameron, E.R.; Onions, D.E.; Campbell, M.E. Tumours derived from HTLV-I tax transgenic mice are characterized by enhanced levels of apoptosis and oncogene expression. J. Pathol. 1998, 186, 209-214. [CrossRef]

76. Haoudi, A.; Semmes, O.J. The HTLV-1 tax oncoprotein attenuates DNA damage induced G1 arrest and enhances apoptosis in p53 null cells. Virology 2003, 305, 229-239. [CrossRef] [PubMed]

77. Rivera-Walsh, I.; Waterfield, M.; Xiao, G.; Fong, A.; Sun, S.C. NF-kappab signaling pathway governs trail gene expression and human T-cell leukemia virus-I tax-induced T-cell death. J. Biol. Chem. 2001, 276, 40385-40388. [CrossRef] [PubMed]

78. Yamada, T.; Yamaoka, S.; Goto, T.; Nakai, M.; Tsujimoto, Y.; Hatanaka, M. The human T-cell leukemia virus type I Tax protein induces apoptosis which is blocked by the Bcl-2 protein. J. Virol. 1994, 68, 3374-3379. [PubMed]

79. Tsukahara, T.; Kannagi, M.; Ohashi, T.; Kato, H.; Arai, M.; Nunez, G.; Iwanaga, Y.; Yamamoto, N.; Ohtani, K.; Nakamura, M.; et al. Induction of Bcl-x(L) expression by human T-cell leukemia virus type 1 Tax through NF-kappaB in apoptosis-resistant T-cell transfectants with Tax. J. Virol. 1999, 73, 7981-7987. [PubMed]

80. Takahashi, M.; Higuchi, M.; Makokha, G.N.; Matsuki, H.; Yoshita, M.; Tanaka, Y.; Fujii, M. HTLV-1 Tax oncoprotein stimulates ROS production and apoptosis in T cells by interacting with USP10. Blood 2013, 122, 715-725. [CrossRef] [PubMed]

81. Hoenicke, L.; Zender, L. Immune surveillance of senescent cells-Biological significance in cancer- and non-cancer pathologies. Carcinogenesis 2012, 33, 1123-1126. [CrossRef] [PubMed]

82. Barbeau, B.; Mesnard, J.M. Making sense out of antisense transcription in human T-cell lymphotropic viruses (HTLVs). Viruses 2011, 3, 456-468. [CrossRef] [PubMed]

83. Clerc, I.; Polakowski, N.; André-Arpin, C.; Cook, P.; Barbeau, B.; Mesnard, J.M.; Lemasson, I. An interaction between the human T cell leukemia virus type 1 basic leucine zipper factor (HBZ) and the KIX domain of p300/CBP contributes to the downregulation of tax-dependent viral transcription by HBZ. J. Biol. Chem. 2008, 283, 23903-23913. [CrossRef] [PubMed]

84. Lemasson, I.; Lewis, M.R.; Polakowski, N.; Hivin, P.; Cavanagh, M.H.; Thebault, S.; Barbeau, B.; Nyborg, J.K.; Mesnard, J.M. Human T-cell leukemia virus type 1 (HTLV-1) bZIP protein interacts with the cellular transcription factor CREB to inhibit HTLV-1 transcription. J. Virol. 2007, 81, 1543-1553. [CrossRef] [PubMed]

85. Gaudray, G.; Gachon, F.; Basbous, J.; Biard-Piechaczyk, M.; Devaux, C.; Mesnard, J.M. The complementary strand of the human T-cell leukemia virus type 1 RNA genome encodes a bZIP transcription factor that down-regulates viral transcription. J. Virol. 2002, 76, 12813-12822. [CrossRef] [PubMed]

86. Zhao, T.; Yasunaga, J.; Satou, Y.; Nakao, M.; Takahashi, M.; Fujii, M.; Matsuoka, M. Human T-cell leukemia virus type 1 bZIP factor selectively suppresses the classical pathway of NF-kappaB. Blood 2009, 113, 2755-2764. [CrossRef] [PubMed]

87. Zhi, H.; Zahoor, M.A.; Shudofsky, A.M.; Giam, C.Z. KSHV vCyclin counters the senescence/G1 arrest response triggered by NF-kB hyperactivation. Oncogene 2014, 34, 496-505. [CrossRef] [PubMed]

88. Fontenot, J.D.; Gavin, M.A.; Rudensky, A.Y. Foxp3 programs the development and function of CD4+CD25+ regulatory T cells. Nat. Immunol. 2003, 4, 330-336. [CrossRef] [PubMed]

89. Grant, C.; Oh, U.; Fugo, K.; Takenouchi, N.; Griffith, C.; Yao, K.; Newhook, T.E.; Ratner, L.; Jacobson, S. Foxp3 represses retroviral transcription by targeting both NF-kB and CREB pathways. PLoS Pathog. 2006, 2, e33. [CrossRef] [PubMed] 
90. Bettelli, E.; Dastrange, M.; Oukka, M. Foxp3 interacts with nuclear factor of activated T cells and NF- $\mathrm{kB}$ to repress cytokine gene expression and effector functions of T helper cells. Proc. Natl. Acad. Sci. USA 2005, 102, 5138-5143. [CrossRef] [PubMed]

91. Chen, S.; Ishii, N.; Ine, S.; Ikeda, S.; Fujimura, T.; Ndhlovu, L.C.; Soroosh, P.; Tada, K.; Harigae, H.; Kameoka, J.; et al. Regulatory T cell-like activity of Foxp3+ adult T cell leukemia cells. Int. Immunol. 2006, 18, 269-277. [CrossRef] [PubMed]

92. Kawata, S.; Ariumi, Y.; Shimotohno, K. p21(Waf1/Cip1/Sdi1) prevents apoptosis as well as stimulates growth in cells transformed or immortalized by human T-cell leukemia virus type 1-encoded tax. J. Virol. 2003, 77, 7291-7299. [CrossRef] [PubMed]

93. Watanabe, M.; Nakahata, S.; Hamasaki, M.; Saito, Y.; Kawano, Y.; Hidaka, T.; Yamashita, K.; Umeki, K.; Taki, T.; Taniwaki, M.; et al. Downregulation of CDKN1A in adult T-cell leukemia/lymphoma despite overexpression of CDKN1A in human T-lymphotropic virus 1-infected cell lines. J. Virol. 2010, 84, 6966-6977. [CrossRef] [PubMed]

94. Jeang, K.T.; Giam, C.Z.; Majone, F.; Aboud, M. Life, death, and tax: Role of HTLV-I oncoprotein in genetic instability and cellular transformation. J. Biol. Chem. 2004, 279, 31991-31994. [CrossRef] [PubMed]

95. Lemoine, F.J.; Marriott, S.J. Genomic instability driven by the human T-cell leukemia virus type I (HTLV-I) oncoprotein, tax. Oncogene 2002, 21, 7230-7234. [CrossRef] [PubMed]

96. Jeang, K.T.; Widen, S.G.; Semmes, O.J.; Wilson, S.H. HTLV-I trans-activator protein, tax, is a trans-repressor of the human beta-polymerase gene. Science 1990, 247, 1082-1084. [CrossRef] [PubMed]

97. Baydoun, H.H.; Cherian, M.A.; Green, P.; Ratner, L. Inducible nitric oxide synthase mediates DNA double strand breaks in human T-cell leukemia virus type 1-induced leukemia/lymphoma. Retrovirology 2015, 12, 71. [CrossRef] [PubMed]

98. Belgnaoui, S.M.; Fryrear, K.A.; Nyalwidhe, J.O.; Guo, X.; Semmes, O.J. The viral oncoprotein tax sequesters DNA damage response factors by tethering MDC1 to chromatin. J. Biol. Chem. 2010, 285, 32897-32905. [CrossRef] [PubMed]

99. Haoudi, A.; Daniels, R.C.; Wong, E.; Kupfer, G.; Semmes, O.J. Human T-cell leukemia virus-I tax oncoprotein functionally targets a subnuclear complex involved in cellular DNA damage-response. J. Biol. Chem. 2003, 278, 37736-37744. [CrossRef] [PubMed]

100. Gupta, S.K.; Guo, X.; Durkin, S.S.; Fryrear, K.F.; Ward, M.D.; Semmes, O.J. Human T-cell leukemia virus type 1 Tax oncoprotein prevents DNA damage-induced chromatin egress of hyperphosphorylated CHK2. J. Biol. Chem. 2007, 282, 29431-29440. [CrossRef] [PubMed]

101. Durkin, S.S.; Guo, X.; Fryrear, K.A.; Mihaylova, V.T.; Gupta, S.K.; Belgnaoui, S.M.; Haoudi, A.; Kupfer, G.M.; Semmes, O.J. HTLV-1 Tax oncoprotein subverts the cellular DNA damage response via binding to DNA-dependent protein kinase. J. Biol. Chem. 2008, 283, 36311-36320. [CrossRef] [PubMed]

102. Ho, Y.K.; Zhi, H.; Bowlin, T.; Dorjbal, B.; Philip, S.; Zahoor, M.A.; Shih, H.M.; Semmes, O.J.; Schaefer, B.; Glover, J.N.; et al. HTLV-1 tax stimulates ubiquitin E3 ligase, ring finger protein 8, to assemble lysine 63-linked polyubiquitin chains for TAK1 and IKK activation. PLoS Pathog. 2015, 11, e1005102. [CrossRef] [PubMed]

103. Deng, L.; Wang, C.; Spencer, E.; Yang, L.; Braun, A.; You, J.; Slaughter, C.; Pickart, C.; Chen, Z.J. Activation of the IkappaB kinase complex by TRAF6 requires a dimeric ubiquitin-conjugating enzyme complex and a unique polyubiquitin chain. Cell 2000, 103, 351-361. [CrossRef]

104. Ea, C.K.; Deng, L.; Xia, Z.P.; Pineda, G.; Chen, Z.J. Activation of IKK by TNFalpha requires site-specific ubiquitination of RIP1 and polyubiquitin binding by NEMO. Mol. Cell 2006, 22, 245-257. [CrossRef] [PubMed]

105. Liu, S.; Chen, Z.J. Expanding role of ubiquitination in NF-kB signaling. Cell Res. 2011, 21, 6-21. [CrossRef] [PubMed]

106. Adhikari, A.; Xu, M.; Chen, Z.J. Ubiquitin-mediated activation of TAK1 and IKK. Oncogene 2007, 26, 3214-3226. [CrossRef] [PubMed]

107. Shembade, N.; Harhaj, N.S.; Yamamoto, M.; Akira, S.; Harhaj, E.W. The human T-cell leukemia virus type 1 Tax oncoprotein requires the ubiquitin-conjugating enzyme Ubc13 for NF-kappaB activation. J. Virol. 2007, 81, 13735-13742. [CrossRef] [PubMed] 
108. Shibata, Y.; Tanaka, Y.; Gohda, J.; Inoue, J. Activation of the ikappab kinase complex by HTLV-1 tax requires cytosolic factors involved in tax-induced polyubiquitination. J. Biochem. 2011, 150, 679-686. [CrossRef] [PubMed]

109. Wang, C.; Long, W.; Peng, C.; Hu, L.; Zhang, Q.; Wu, A.; Zhang, X.; Duan, X.; Wong, C.C.; Tanaka, Y.; et al. HTLV-1 tax functions as a ubiquitin E3 ligase for direct IKK activation via synthesis of mixed-linkage polyubiquitin chains. PLoS Pathog. 2016, 12, e1005584. [CrossRef] [PubMed]

110. Wu, X.; Sun, S.C. Retroviral oncoprotein Tax deregulates NF-kappaB by activating Tak1 and mediating the physical association of Tak1-IKK. EMBO Rep. 2007, 8, 510-515. [CrossRef] [PubMed]

111. Ho, Y.K.; Zhi, H.; Debiaso, D.; Philip, S.; Shih, H.M.; Giam, C.Z. HTLV-1 tax-induced rapid senescence is driven by the transcriptional activity of NF-KB and depends on chronically activated IKK $\alpha$ and p65/RelA. J. Virol. 2012, 86, 9474-9483. [CrossRef] [PubMed]

112. Hayakawa, M. Role of K63-linked polyubiquitination in NF-kappaB signalling: Which ligase catalyzes and what molecule is targeted? J. Biochem. 2012, 151, 115-118. [CrossRef] [PubMed]

113. Pinder, J.B.; Attwood, K.M.; Dellaire, G. Reading, writing, and repair: The role of ubiquitin and the ubiquitin-like proteins in DNA damage signaling and repair. Front. Genet. 2013, 4, 45. [CrossRef] [PubMed]

114. Bartocci, C.; Denchi, E.L. Put a ring on it: Regulation and inhibition of RNF8 and RNF168 ring finger E3 ligases at DNA damage sites. Front. Genet. 2013, 4, 128. [CrossRef] [PubMed]

115. Kolas, N.K.; Chapman, J.R.; Nakada, S.; Ylanko, J.; Chahwan, R.; Sweeney, F.D.; Panier, S.; Mendez, M.; Wildenhain, J.; Thomson, T.M.; et al. Orchestration of the DNA-damage response by the RNF8 ubiquitin ligase. Science 2007, 318, 1637-1640. [CrossRef] [PubMed]

116. Mailand, N.; Bekker-Jensen, S.; Faustrup, H.; Melander, F.; Bartek, J.; Lukas, C.; Lukas, J. RNF8 ubiquitylates histones at DNA double-strand breaks and promotes assembly of repair proteins. Cell 2007, 131, 887-900. [CrossRef] [PubMed]

117. Lu, C.S.; Truong, L.N.; Aslanian, A.; Shi, L.Z.; Li, Y.; Hwang, P.Y.; Koh, K.H.; Hunter, T.; Yates, J.R., 3rd; Berns, M.W.; et al. The RING finger protein RNF8 ubiquitinates Nbs1 to promote DNA double-strand break repair by homologous recombination. J. Biol. Chem. 2012, 287, 43984-43994. [CrossRef] [PubMed]

118. Luo, K.; Zhang, H.; Wang, L.; Yuan, J.; Lou, Z. Sumoylation of MDC1 is important for proper DNA damage response. EMBO J. 2012, 31, 3008-3019. [CrossRef] [PubMed]

119. Siu, Y.T.; Chin, K.T.; Siu, K.L.; Yee Wai, C.E.; Jeang, K.T.; Jin, D.Y. TORC1 and TORC2 coactivators are required for tax activation of the human T-cell leukemia virus type 1 long terminal repeats. J. Virol. 2006, 80, 7052-7059. [CrossRef] [PubMed]

120. Nyborg, J.K.; Egan, D.; Sharma, N. The HTLV-1 Tax protein: Revealing mechanisms of transcriptional activation through histone acetylation and nucleosome disassembly. Biochim. Biophys. Acta 2009, 1799, 266-274. [CrossRef] [PubMed]

121. Xu, X.; Heidenreich, O.; Kitajima, I.; McGuire, K.; Li, Q.; Su, B.; Nerenberg, M. Constitutively activated JNK is associated with HTLV-1 mediated tumorigenesis. Oncogene 1996, 13, 135-142. [PubMed]

122. Chariot, A. The NF-kappaB-independent functions of IKK subunits in immunity and cancer. Trends Cell Biol 2009, 19, 404-413. [CrossRef] [PubMed]

123. Lee, D.F.; Kuo, H.P.; Chen, C.T.; Hsu, J.M.; Chou, C.K.; Wei, Y.; Sun, H.L.; Li, L.Y.; Ping, B.; Huang, W.C.; et al. IKK beta suppression of TSC1 links inflammation and tumor angiogenesis via the mTOR pathway. Cell 2007, 130, 440-455. [CrossRef] [PubMed]

124. Emmerich, C.H.; Ordureau, A.; Strickson, S.; Arthur, J.S.; Pedrioli, P.G.; Komander, D.; Cohen, P. Activation of the canonical IKK complex by K63/M1-linked hybrid ubiquitin chains. Proc. Natl. Acad. Sci. USA 2013, 110, 15247-15252. [CrossRef] [PubMed]

125. Peloponese, J.M., Jr.; Haller, K.; Miyazato, A.; Jeang, K.T. Abnormal centrosome amplification in cells through the targeting of Ran-binding protein- 1 by the human T cell leukemia virus type- 1 Tax oncoprotein. Proc. Natl. Acad. Sci. USA 2005, 102, 18974-18979. [CrossRef] [PubMed]

126. Ching, Y.P.; Chan, S.F.; Jeang, K.T.; Jin, D.Y. The retroviral oncoprotein tax targets the coiled-coil centrosomal protein TAX1BP2 to induce centrosome overduplication. Nat. Cell Biol. 2006, 8, 717-724. [CrossRef] [PubMed]

127. Jin, D.Y.; Spencer, F.; Jeang, K.T. Human T cell leukemia virus type 1 oncoprotein Tax targets the human mitotic checkpoint protein MAD1. Cell 1998, 93, 81-91. [CrossRef] 
128. Liu, B.; Hong, S.; Tang, Z.; Yu, H.; Giam, C.Z. HTLV-I Tax directly binds the Cdc20-associated anaphase-promoting complex and activates it ahead of schedule. Proc. Natl. Acad. Sci. USA 2005, 102, $63-68$. [CrossRef] [PubMed]

129. Bellon, M.; Baydoun, H.H.; Yao, Y.; Nicot, C. HTLV-I Tax-dependent and -independent events associated with immortalization of human primary T lymphocytes. Blood 2010, 115, 2441-2448. [CrossRef] [PubMed]

130. Luijsterburg, M.S.; Acs, K.; Ackermann, L.; Wiegant, W.W.; Bekker-Jensen, S.; Larsen, D.H.; Khanna, K.K.; van Attikum, H.; Mailand, N.; Dantuma, N.P. A new non-catalytic role for ubiquitin ligase RNF8 in unfolding higher-order chromatin structure. EMBO J 2012, 31, 2511-2527. [CrossRef] [PubMed]

131. Chahwan, R.; Gravel, S.; Matsusaka, T.; Jackson, S.P. Dma/RNF8 proteins are evolutionarily conserved E3 ubiquitin ligases that target septins. Cell Cycle 2013, 12, 1000-1008. [CrossRef] [PubMed]

132. Plans, V.; Guerra-Rebollo, M.; Thomson, T.M. Regulation of mitotic exit by the RNF8 ubiquitin ligase. Oncogene 2008, 27, 1355-1365. [CrossRef] [PubMed]

133. Ghirlando, R.; Felsenfeld, G. Ctcf: Making the right connections. Genes Dev. 2016, 30, 881-891. [CrossRef] [PubMed]

134. Satou, Y.; Miyazato, P.; Ishihara, K.; Yaguchi, H.; Melamed, A.; Miura, M.; Fukuda, A.; Nosaka, K.; Watanabe, T.; Rowan, A.G.; et al. The retrovirus HTLV-1 inserts an ectopic CTCF-binding site into the human genome. Proc. Natl. Acad. Sci. USA 2016, 113, 3054-3059. [CrossRef] [PubMed]

135. Landry, S.; Halin, M.; Vargas, A.; Lemasson, I.; Mesnard, J.M.; Barbeau, B. Upregulation of human T-cell leukemia virus type 1 antisense transcription by the viral tax protein. J. Virol. 2009, 83, 2048-2054. [CrossRef] [PubMed]

136. Barbeau, B.; Peloponese, J.M.; Mesnard, J.M. Functional comparison of antisense proteins of HTLV-1 and HTLV-2 in viral pathogenesis. Front. Microbiol. 2013, 4, 226. [CrossRef] [PubMed]

137. Mesnard, J.M.; Barbeau, B.; Devaux, C. HBZ, a new important player in the mystery of adult T-cell leukemia. Blood 2006, 108, 3979-3982. [CrossRef] [PubMed]

138. Kawatsuki, A.; Yasunaga, J.I.; Mitobe, Y.; Green, P.L.; Matsuoka, M. HTLV-1 bZIP factor protein targets the $\mathrm{Rb} / \mathrm{E} 2 \mathrm{~F}-1$ pathway to promote proliferation and apoptosis of primary CD4 T cells. Oncogene 2016. [CrossRef] [PubMed]

139. Yamamoto-Taguchi, N.; Satou, Y.; Miyazato, P.; Ohshima, K.; Nakagawa, M.; Katagiri, K.; Kinashi, T.; Matsuoka, M. HTLV-1 bZIP factor induces inflammation through labile Foxp3 expression. PLoS Pathog. 2013, 9, e1003630. [CrossRef] [PubMed]

140. Vernin, C.; Thenoz, M.; Pinatel, C.; Gessain, A.; Gout, O.; Delfau-Larue, M.H.; Nazaret, N.; Legras-Lachuer, C.; Wattel, E.; Mortreux, F. HTLV-1 bZIP factor HBZ promotes cell proliferation and genetic instability by activating oncomirs. Cancer Res. 2014, 74, 6082-6093. [CrossRef] [PubMed]

141. Kuhlmann, A.S.; Villaudy, J.; Gazzolo, L.; Castellazzi, M.; Mesnard, J.M.; Duc, D.M. HTLV-1 HBZ cooperates with jund to enhance transcription of the human telomerase reverse transcriptase gene (hTERT). Retrovirology 2007, 4, 92. [CrossRef] [PubMed]

142. Yasuma, K.; Yasunaga, J.; Takemoto, K.; Sugata, K.; Mitobe, Y.; Takenouchi, N.; Nakagawa, M.; Suzuki, Y.; Matsuoka, M. HTLV-1 bZIP factor impairs anti-viral immunity by inducing co-inhibitory molecule, T cell immunoglobulin and ITIM domain (TIGIT). PLoS Pathog. 2016, 12, e1005372. [CrossRef] [PubMed]

143. Charvet, C.; Canonigo, A.J.; Becart, S.; Maurer, U.; Miletic, A.V.; Swat, W.; Deckert, M.; Altman, A. Vav1 promotes $\mathrm{T}$ cell cycle progression by linking TCR/CD28 costimulation to FOXO1 and p27kip1 expression. J. Immunol. 2006, 177, 5024-5031. [CrossRef] [PubMed]

(C) 2016 by the authors; licensee MDPI, Basel, Switzerland. This article is an open access article distributed under the terms and conditions of the Creative Commons Attribution (CC-BY) license (http://creativecommons.org/licenses/by/4.0/). 